\title{
Fluid inclusion analysis of twinned selenite gypsum beds from the Miocene of the Madrid basin (Spain). Implication on dolomite bioformation
}

\author{
F. Ayllón-Quevedo ${ }^{\text {a }}$, V. Souza-Egipsy ${ }^{\mathrm{a}, *}$, M.E. Sanz-Montero ${ }^{\mathrm{b}}$, J.P. Rodríguez-Aranda ${ }^{\mathrm{b}}$ \\ ${ }^{a}$ Centro de Astrobiología, INTA-CSIC, Carretera de Ajalvir, Km 4, 28850, Torrejón de Ardoz, Madrid, Spain \\ b Departamento de Petrología y Geoquímica, Facultad de Geología, Universidad Complutense, 28040-Madrid, Spain
}

\begin{abstract}
This research work is centred on continental lacustrine gypsum deposits of Miocene age cropping out in the easternmost part of the Madrid Basin. These gypsum deposits, accumulated in a continental saline lake, are characterized by a spectacular, distinctive Christmas-tree morphology and a peculiar dolomite replacement. A combination of microscopic (petrography and scanning electron microscopy) and analytical techniques (fluid inclusion microthermometry, X-ray energy dispersive spectroscopy and X-ray diffractometry) was used in order to study the crystallographic distribution and the composition of the fluid inclusions within the gypsum. The objectives were to characterize the continental brine from which the mineral precipitated, and to detect mineral and element traces that could indicate early diagenetic processes altering the gypsum deposits. Data from primary fluid inclusions indicated that gypsum precipitated from an aqueous fluid (lake water) of low to moderate total salinity (between 20 and $90 \mathrm{~g} / \mathrm{L} \mathrm{NaCl}$ ). Secondary fluid inclusions represent interstitial lake brine in contact with gypsum, slightly enriched in total salt content as crystal formation proceeded. Textural, ultrastructural and microanalytical analysis indicate that the presence of dolomite precipitates inside the gypsum layers is related to the microbial colonization of the gypsum deposits and the biomineralization of the cell walls and extracellular polymeric substances around the cells. Our investigation emphasizes necessity of a multidisciplinary approach to assess geobiological processes.
\end{abstract}

Keywords: Evaporite lake; Palaeosalinities; Dolomite; Biomineralization

\section{Introduction}

The Miocene Christmas-tree gypsum formation from the Madrid basin has been mineralogicaly and sedimen-tologicaly characterized in previous works (Rodríguez-Aranda et al., 1995a). However, there are still some peculiar aspects that need specific techniques in order to

* Corresponding author. Tel.: +34 91520 6405; fax: +34 915201074. E-mail address: souzaev@inta.es (V. Souza-Egipsy). elucidate the mechanisms involved in the development of this formation. This particular gypsum formation presents an atypical growth together with a peculiar dolomite replacement (Rodríguez-Aranda et al., 1995a; Sanz-Montero et al., 2003; Rodríguez-Aranda et al., 2004; Sanz-Montero et al., 2006). Isotopic analysis of the dolomite samples yielded $\delta^{13} \mathrm{C}$-values ranging from -7.35 to $-4.65 \%$ o PDB (Sanz-Montero et al., 2003) suggesting a biological implication in the carbonate precipitation. 
Actual dolomite precipitation and dolomite deposits is commonly, although not exclusively, associated to evaporitic environments such as the marginalmarine Coorong lakes (Von der Borch, 1976; Rosen et al., 1989; Wright and Wacey, 2005), the hypersaline coastal lagoons (Vasconcelos et al., 1995; Vasconcelos and McKenzie, 1997; Warthmann et al., 2005), and the sabkhas of Abu Dhabi (Evans et al., 1969; McKenzie et al., 1980). Sedimentary dolomite has been described in some lacustrine systems (Last, 1990; García del Cura et al., 2001) as well as in deep sea organic-rich sedi-ments (Kelts and McKenzie, 1982). Recently, dolomite precipitation has also been linked with microbial ac-tivity in a methanogenic groundwater system (Roberts et al., 2004), hypersaline continental areas (Corzo et al., 2005), and in organic carbon-rich upweling related sediments of the Peru margin ODP 201 (Meister et al., 2006). In most modern environments dolomite pre-cipitation is linked with microbial sulphate reduction (Vasconcelos and McKenzie, 1997; Wright, 1999; van Lith et al., 2002; Moreira et al., 2004; Wright and Wacey, 2005; Warthmann et al., 2005). These studies focus on modern materials and processes to describe how microbes affect the composition of the sediments. The role of microbial communities in providing a distinctive structure and/or composition to sediments has been studied from natural to laboratory samples. Laboratory experiments showed that nucleation process- es on microbial cells or on extracellular polymeric sub-stances controlled microbial carbonate formation in environments that simulated early Earth conditions (Bosak and Newman, 2003; Aloisi et al., 2006). Laboratory studies under modern conditions provide in-formation about the chemical features of the surround-ing fluids that influenced the composition of the final precipitates (Dittrich et al., 2003, 2004; Benzerara et al., 2004). Moreover, the study of natural samples provide information on the distribution and textural features of the minerals precipitated in the microenvironment where the organisms are present (Thompson and Ferris, 1990; Léveillé et al., 2000; Souza-Egipsy et al., 2005). The combination of these studies is necessary to understand how microbes can affect the chemical composition of the sediments. In this study, our approach was to use a set of microscopical and microanalytical techniques in order to describe the microstructure and the conditions of the microenvironment under which dolomite precipitated in-side the gypsum crystals of the Christmas-tree formation. Fluid inclusions are cavities in minerals that retain the ambient fluids from which crystals grew or which were in contact with the minerals after their formation (Roedder, 1984a). Microthermometry is the most widely applied analytical technique to characterize fluids' salinity and basic salt content, by measuring the melting point temperatures of water ice and salt hydrates- if present-(Roedder, 1984b; Goldstein and Reynolds, 1994).

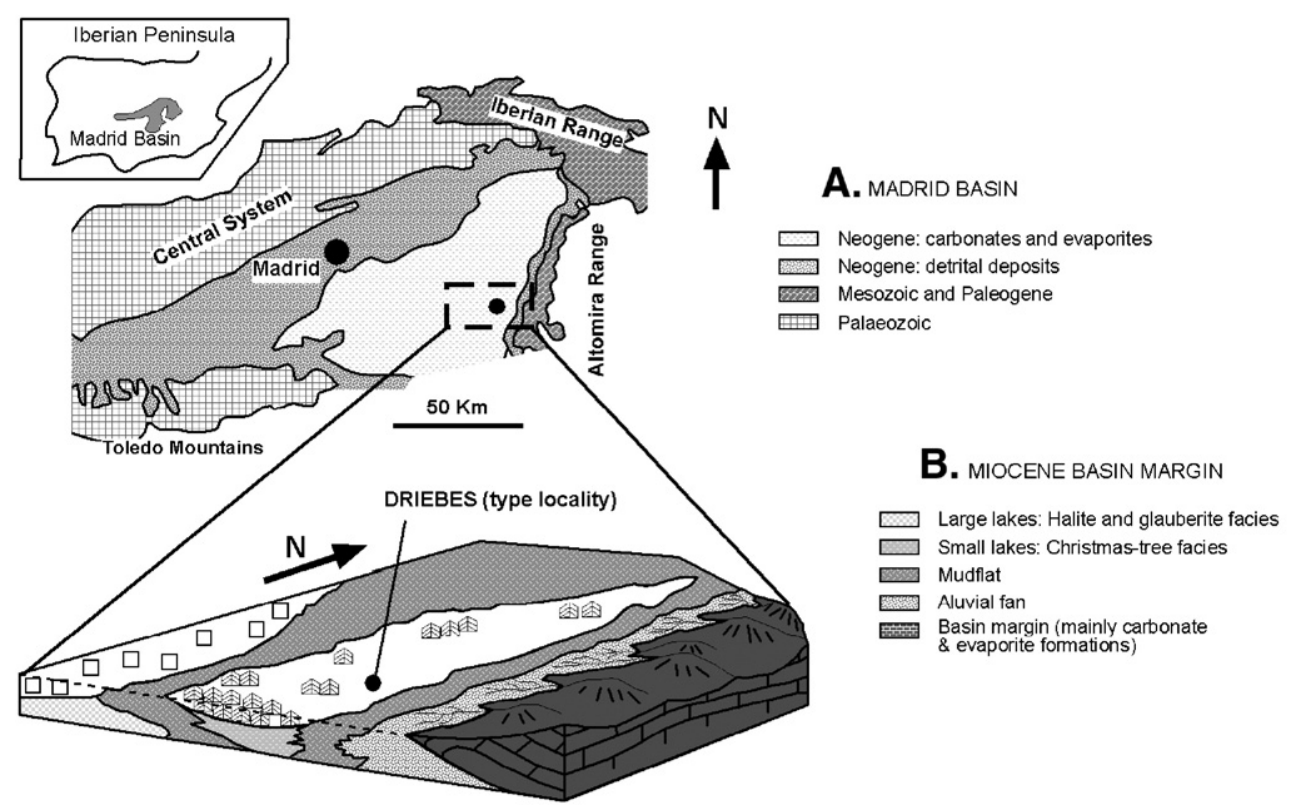

Fig. 1. A. Simplified geological sketch map of the Madrid Basin showing the localization of the study area, Driebes. B. Palaeoenvironmental reconstruction of the basin margin and sedimentary model of the Christmas-tree gypsum formation during the Aragonian (Miocene), after Rodríguez-Aranda et al. (1995a). 
However, to assess more precisely the chemical composition of the inclusions' fluid other techniques are necessary. Measurements using Low Temperature Scanning Microscopy temperatures (LTSEM or CryoSEM) allow the qualitative and quantitative elemental characterization of the host minerals and the fluids uniformly frozen mass. This technique was first introduced for evaporitic minerals by Ayora and Fontarnau (1990) and more specifically applied by García-Veigas (1993) and Ayora et al. (1994) in the study of saline inclusions in halite.

Fluid inclusions within the gypsum crystals of the Christmas-tree facies have been extensively investigated in samples from the type locality of Driebes with the aim of: (1) characterizing the continental brine from which gypsum, and possibly dolomite precipitated, (2) asses-sing possible traces of early diagenetic fluid activity and post-precipitation conditions, and (3) obtaining a model for the distribution of the different types of fluid inclusion assemblages and relate it to both the specific crystallographic and growth features of the Christmastree gypsum crystals. Knowing better the nature of the fluids present during the formation of gypsum deposits would make it possible to understand the chemical constraints that induced the formation of these atypical gypsum deposits, and also to determine the conditions of formation of the dolomite inside gypsum deposits.

\section{Geological setting and area description}

The studied gypsum deposits are located in the cinity of the village of Driebes, Guadalajara province, vi-

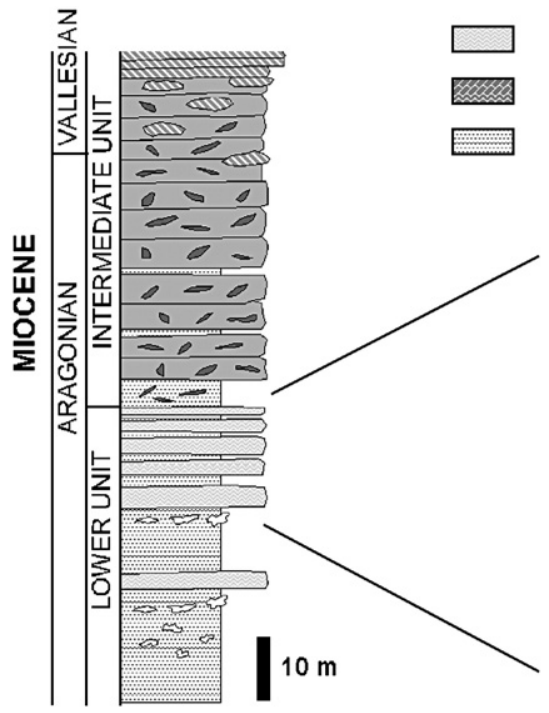

Spain. They are from the eastern part of the Madrid Basin, a continental fault-bounded intracratonic basin in the Iberian Peninsula (Fig. 1A). The Neogene sedimen-tary record of this basin has been divided into three Miocene stratigraphic units (Lower, Intermediate and Upper units), which span from Ramblian to late Turolian stages (Calvo et al., 1989). According to Rodríguez-Aranda et al. (1995a,b), the formation was deposited in a mudflat-saline lake complex isolated from the hypersaline lake developed in the central parts of the basin during the Miocene Aragonian stage (Fig. 1B). In the Driebes area, the Neogene sedimentary record only consists of the Lower and Intermediate Miocene units, which lie horizontally (Fig. 2).

The Christmas-tree gypsum formation is present in the upper $50 \mathrm{~m}$ of the Lower Unit (from 25 to $15 \mathrm{Ma}$ ) and is overlain by an alternation of carbonate, gypsum and mudstone deposits which belong to the Intermediate Unit (Fig. 2). The Christmas-tree gypsum formation comprises gypsum, mudstone, marl and dolostone. Gypsum deposits mainly occur as a $15 \mathrm{~m}$ thick succession located in the uppermost part of the formation (Fig. 2). The unit is informally referred to as the Christmas-tree gypsum formation due to the external morphology of the growth-aligned gypsum beds in vertical sections parallel to (010) surfaces (Fig. $3)$. These are composed of macrocrystalline (100) twinned selenite crystals displaying a habit characterized by the twin re-entrant angles systematically opening downward, in opposition to the commonly accepted Mottura's rule (Ogniben, 1954). Commonly, the crystals are $2-11 \mathrm{~cm}$ width, $8-30 \mathrm{~cm}$ height, and 10

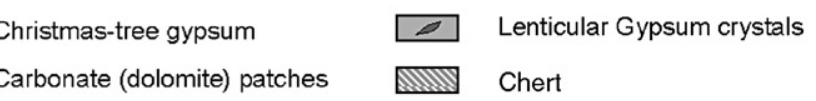

Mudstone-marlstone $\infty$ Anhydrite nodules

DRIEBES SECTION

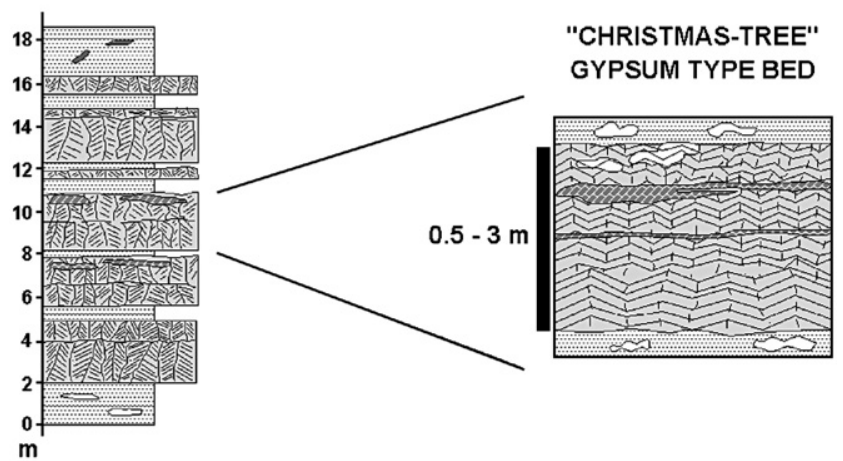

Fig. 2. A. Stratigraphic column of the Madrid Basin for the Aragonian (Miocene). B-C. Stratigraphic sections illustrating features of the Christmas-tree gypsum formation from outcrops near Driebes. Modified from Rodríguez-Aranda et al. (1995a). 


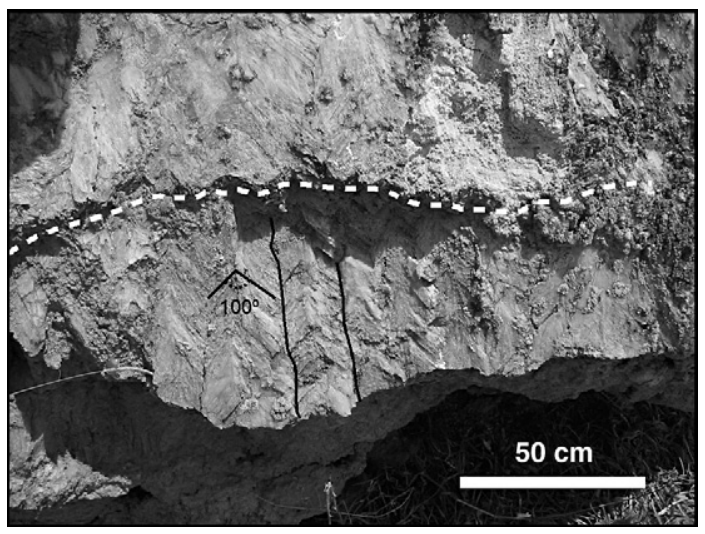

Fig. 3. Outcrop view of the gypsum beds at Driebes, showing typical vertical-growing Christmas-tree morphology and dolomite laminae (dashed line). Vertical lines underline intergrowth surfaces between crystals. Typically, the outcrop surfaces arrange parallel to the main (010) cleavage of gypsum.

$30 \mathrm{~cm}$ in horizontal length, as seen on sections parallel to the (010) cleavage and also on the bed plane. In detail, the gypsum consists of $\mathrm{mm}$ - to cm-sized subcrystals showing epitaxial growth according to a regular pattern (Rodríguez-Aranda et al., 1995a). The Christmas-tree gypsum denomination for selenite crystals has been followed in this work (Fort et al., 1982), although the three-dimensional crystalline pattern exactly does not fit a Christmas-tree. This tree appearance is observed in the sections parallel to the main cleavage (010) of gypsum, which is the dominant surface recognizable in outcrops. A more precise alternative name for selenites could be 'house-roof gypsum', because the crystals are elongated along the horizontal $b$-axis, not along the vertical c-axis (Rodríguez-Aranda et al., 1995b).

Anhydrite laths and secondary gypsum after anhy-drite are locally present within the crystals and as re-placement nodules, respectively. The sequence is made up of gypsum tabular beds ranging $0.5-3 \mathrm{~m}$ in thickness, separated by marlstone beds of $0.6 \mathrm{~m}$ maximum thick-ness (Fig. 2). Each gypsum bed comprises typically minor single beds $8-30 \mathrm{~cm}$ thick that are unevenly outlined by $\mathrm{cm}-\mathrm{dm}$ thick discontinuous dolomite beds (Fig. 2). Dolomite beds show the typical domal and pustular morphologies of stromatolites (Rodríguez-Aranda et al., 2004). Dolomite also occurs as layers outlining and/or between subcrystals in gypsum beds.

3. Materials and analytical methods

\subsection{Sampling}

A total of 37 samples of dolomite and gypsum rocks have been taken from different beds of the Christmas- tree gypsum succession cropping out near Driebes (Figs. 1 and 2). Additionally, four cylindrical cores up to $12 \mathrm{~cm}$ in length and $10 \mathrm{~cm}$ in diameter were extracted using a rock drill to avoid external weathered surfaces and the study of samples colonized by epilithic lichens and mosses.

\subsection{Optical microscopy}

Mineral and fluid inclusion petrography were studied in thin $(30 \mu \mathrm{m})$ and double polished $(100-200 \mu \mathrm{m}$ thick) sections from the same rock cuts, using a Nikon E600 Pol optical microscope with both reflected and transmitted light. Sections used for the anal-ysis of fluid inclusions were embedded, when neces-sary, with epoxy resin, polishing with a mixture of silicon carbide and SAE 10 oil, and fixing to the glass with cyanocrylate glue. Gypsum material colo-nized with endolithic cyanobacteria was observed under an epifluorescence Zeiss Axioskop 2 micro-scope. Epifluorescence images of the thin sections were obtained with an Olympus BX51 equipped with a URFL-T.

\subsection{Microthermometry}

Fluid inclusions were studied in the double polished thin sections of the Christmas-tree gypsum crystals. Three sections were prepared from orientated cuts along the (010), (100), and c-axis perpendicular plains, according to Rodríguez-Aranda et al. (1995a) crystallo-graphic model. Microthermometric measurements were made using a Linkam THMS 600 stage and the same microscope facility as above. Calibration was performed using 3 types of synthetic fluid inclusions, supplied by the Mineralogy and Petrology Department of the University of Leoben (Austria): $\mathrm{H}_{2} \mathrm{O}-\mathrm{NaCl}$ at $-21.1^{\circ} \mathrm{C}, \mathrm{H}_{2} \mathrm{O}-\mathrm{CO}_{2}$ at $-56.6^{\circ}$ $\mathrm{C}$ and $9.9{ }^{\circ} \mathrm{C}$, and pure $\mathrm{H}_{2} \mathrm{O}$ at $0.0^{\circ} \mathrm{C}$ and $+374{ }^{\circ} \mathrm{C}$. The heating/cooling rate used was $5{ }^{\circ} \mathrm{C} \mathrm{min}{ }^{-1}$, and as homogenisation/melting approached the rate was reduced to $2-1{ }^{\circ} \mathrm{C}$ and $1{ }^{\circ} \mathrm{C}$, respectively.

\subsection{X-ray diffraction analysis}

X-ray diffraction was used to determine mineral composition in 31 powdered samples from different beds of the Christmas-tree gypsum succession cropping out near Driebes (Figs. 1 and 2), using quartz as an internal standard. The samples were produced by grind-ing in an agate mortar to obtain powders of b0.1 mm grain size. The equipment used was a Philips X-ray 
diffraction system operated at $40 \mathrm{kV}$ and $30 \mathrm{~mA}$, and monochromated $\mathrm{Cu}-\mathrm{K} \alpha$ radiation. Values of $\mathrm{mol} \%$ $\mathrm{CaCO}_{3}$ of the carbonate minerals were estimated by measurement of the position of the $\mathrm{d}_{104}$ peak relative to a standard (Goldsmith et al., 1961). The degree of ordering of the dolomite crystals was determined by the sharpness and relative intensities of the ordering peaks superstructure reflections corresponding to $\mathrm{d}_{021}, \mathrm{~d}_{015}$ and $\mathrm{d}_{110}$ (Goldsmith and Graf, 1958). The degree of ordering was thus estimated by the ratio of the heights of the ordering peak 015 to diffraction peak 110 (Hardy and Tucker, 1988).
3.5. Ultrastructural and microanalytical characterization with Scanning Electron Microscopy with Xray Energy Dispersive Spectroscopy (SEM-EDS)

Scanning electron microscopy studies were con-ducted using a Jeol 5600LV equipped with an INCA Oxford X-ray energy dispersive spectroscopic microan-alytical system. Gypsum samples from Driebes area were chemically fixed in $2.5 \%$ glutaraldehyde in $0.2 \mathrm{M} \mathrm{Na}$-cacodylate buffer ( $\mathrm{pH} 7$ ) for $4 \mathrm{~h}$ at $5{ }^{\circ} \mathrm{C}$. Fixed samples were subsequently washed with buffer and post-fixed with $1 \%$ osmium tetroxide $\left(\mathrm{OsO}_{4}\right)$ in water

A

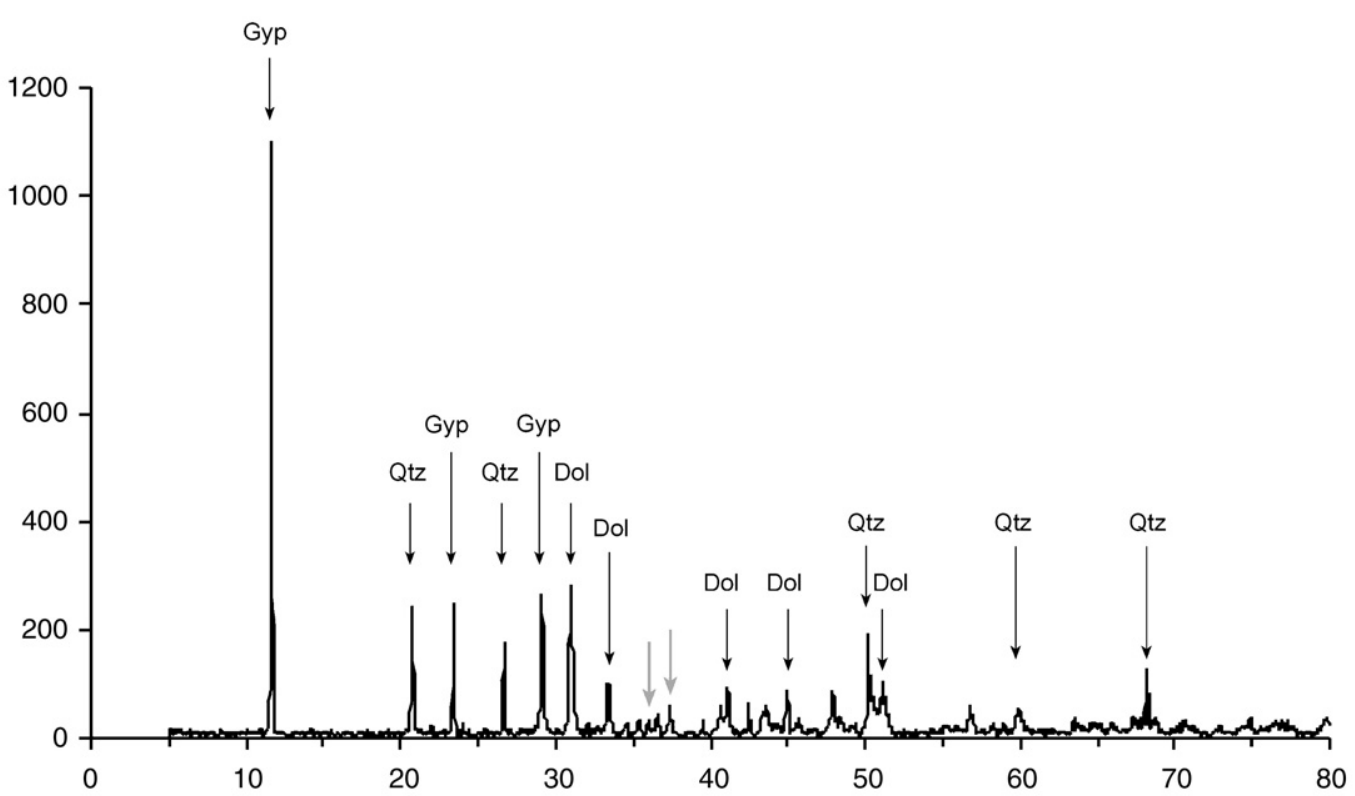

B

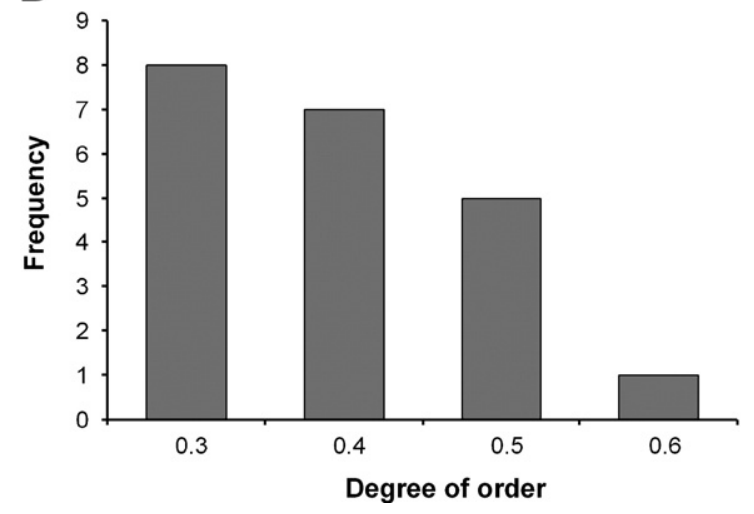

C

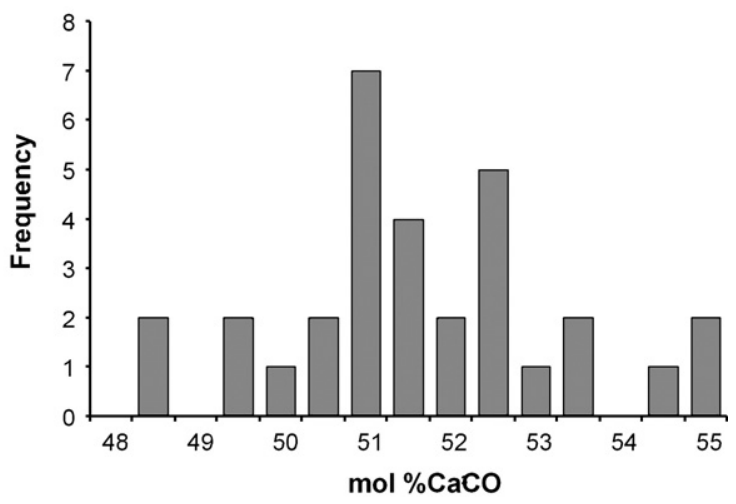

Fig. 4. A. X-ray diffractogram of a powder-preparation, with $10 \%$ quartz added, of a dolomite sample from a typical Christmas-tree gypsum sample, illustrating mineral content. 0.15 and 110 reflections of dolomite are marked by grey arrows. Main peaks are labelled as follows: Gyp= gypsum; Dol= dolomite; $\mathrm{Qtz}=$ quartz. B. Frequency diagram of the degree of order calculated for 21 dolomite samples. C. Frequency diagram of the $\mathrm{mol} \%$ of $\mathrm{CaCO}_{3}$ in 31 dolomite samples. 
for $5 \mathrm{~h}$, and finally washed with distilled water and dehydrated using and ascending series of ethanol. After $12 \mathrm{~h}$ in $100 \%$ ethanol a mixture of ethanol: LR-White (1:1) resin was used. Finally, the samples were infi-ltrated with $100 \% \mathrm{LR}$-white resin for $24 \mathrm{~h}$ at $5{ }^{\circ} \mathrm{C}$ and cured at $65{ }^{\circ} \mathrm{C}$ for $24 \mathrm{~h}$. The samples were polished following protocols as in Ascaso and Wierzchos (1994) and Wierzchos and Ascaso (1994). The samples were carbon-coated and observed at an acceleration voltage of 15-20 kV. EDS microanalytical spectrum anal-ysis were compared with a QCT/A calibration block (Micro-analysis Consultants) with a standard of anhy-drite $(\mathrm{Ca}$, $29.4 \% ; \mathrm{S}, 23.6 \% ; \mathrm{O}, 47.0)$ and calcite $(\mathrm{Ca}, 40 \%$; C, $12 \%$; O, 48\%).

\subsection{Low Temperature Scanning Electron Microscopy (LTSEM)}

Low Temperature Scanning Electron Microscopy (LTSEM or Cryo-SEM), were performed using small oriented pieces of gypsum cut with a razor blade and then mounted and mechanically fixed onto a specimen holder at room temperature. The fragments were immediately plunged frozen in slush nitrogen and directly transferred into the cryo-chamber, pre-cooled to $-180{ }^{\circ} \mathrm{C}$ via an airlock transfer device. The frozen fragment was then fractured with a cooled blade and sputter coated with gold for $2 \mathrm{~min} 15 \mathrm{~s}$ at $10 \mathrm{~mA}$. Then it was moved to the SEM-chamber pre-cooled to -150 ${ }^{\circ} \mathrm{C}$ to $-160{ }^{\circ} \mathrm{C}$ where it was observed at an acceleration voltage of $15-20 \mathrm{kV}$. The instrument used was a CT 1500 Cryotrans system (Oxford Instruments) mounted on a Zeiss 960 SEM.

4. Results

\subsection{Mineralogy and textural relationships}

Typically, the studied samples of the Christmastree gypsum formation were composed of gypsum and do-lomite with minor quantities of anhydrite, celestite, iron oxides and sulphides and scarce clay minerals. The degree of ordering in the dolomite samples, determined by measurement of indices 015 and 110 from X-ray traces (Fig. 4A), ranged from 0.3 to 0.6 , averaging 0.4 (Fig. $4 \mathrm{~B}$ ). These values indicated that the dolomites were poorly ordered (Kinsman, 1964, cited in Bathurst, 1975). According to the $\mathrm{mol} \% \mathrm{CaCO}_{3}$ determined in the dolomites by measurement of the position of the $d_{104}$ peak relative to a standard (Goldsmith et al., 1961), the Miocene dolomites contained 48 to $55 \mathrm{~mol} \% \mathrm{CaCO}_{3}$, with modes at $51 \% \mathrm{Ca}$ and $52.5 \% \mathrm{Ca}$ (Fig. 4C). Thus, they can be characterized as slightly $\mathrm{Ca}-\mathrm{rich}$, and non- stoichiometric. Molar ratios obtained for these dolomite samples from quantitative microprobe analyses by Sanz-Montero et al. (2006) also reflected that most of do-lomite samples were enriched in $\mathrm{Ca}$, and the \%Ca content oscillated nearly in the same range (48-58\%).

A twined gypsum crystal was composed of hundreds of $\mathrm{mm}^{-}$to cm-sized subcrystals that presented a dirty aspect under plane polarized microscope (Fig. 5), mainly due to areas with dolomite replacement. The Christmas-tree selenites were mainly developed hori-zontally due to a higher growth rate of the $\{020\}$ faces (Rodríguez-Aranda et al., 1995b). The (100) contact twin, perpendicular to the former faces, was probably

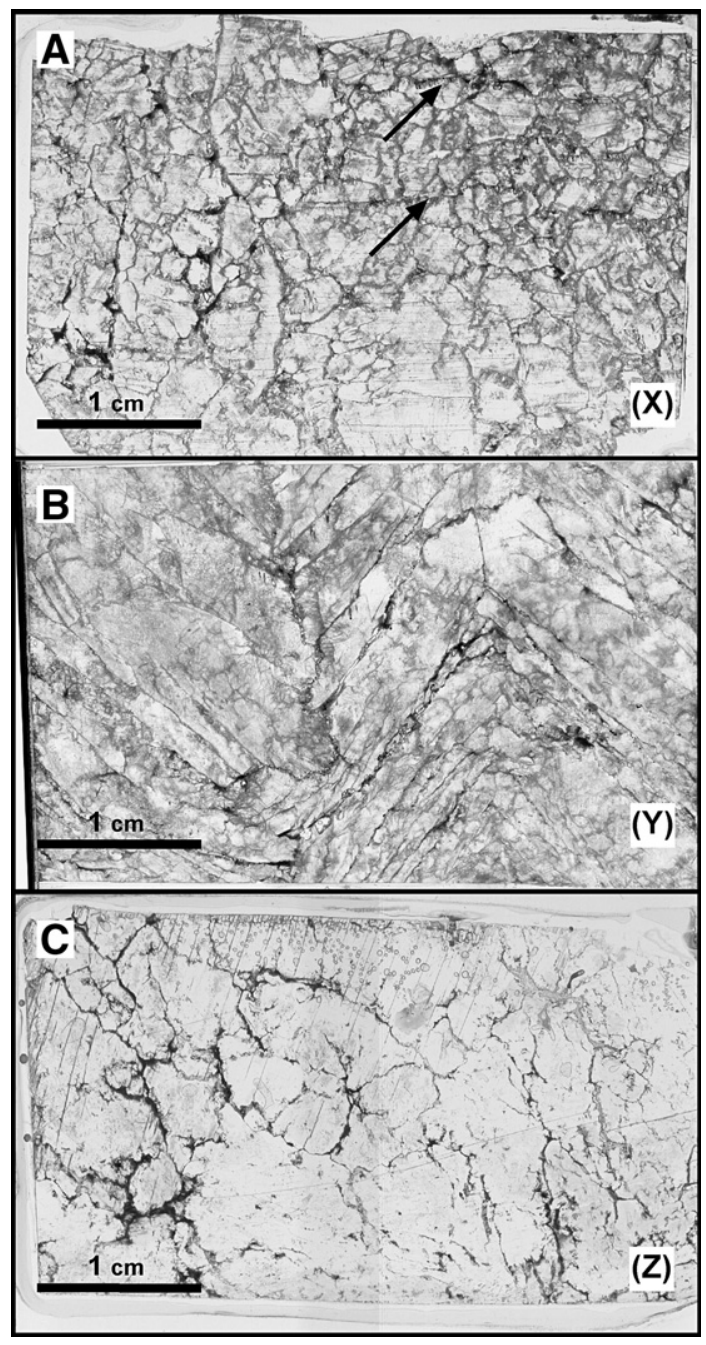

Fig. 5. Photomicrograph's of 3 double polished sections $(200 \mu \mathrm{m})$ from Christmas-tree gypsum facies of the Madrid basin, each cut along one of the three spatial planes: $\mathrm{X}, \mathrm{Y}$ and $\mathrm{Z}$ (according to Rodríguez-Aranda et al., 1995a). A. (X) section perpendicular to caxis. B. (Y) section parallel to (010). C. (Z) section parallel to (100). See also Fig. 8. 
due to the accumulation of crystalline defects as a consequence of that rapid growth. In this pattern, the growth along [101] direction was also high due to the $\{120\}$ and (100) faces crystallization, but limited by competition with adjacent crystals. The growth of the $\{\bar{I} 11\}$ faces would be slow and accompanied by a discontinuous development in the vertical c-axis direction (Rodríguez-Aranda et al., 1995a,b).

The limits of the subcrystals are defined mainly by $\{\overline{1} 11\}$ faces, usually imperfectly developed, together to (010) and $\{120\}$ faces. The twin re-entrant angles are marked by $\{\overline{\mathrm{I}} 11\}$ faces on (010) cleavage (Fig. 5B). The subcrystals grew epitaxially according to a regular pattern, but their boundaries appear unevenly outlined by irregular micro-dissolution surfaces and microtubes (arrows Figs. 5A and 6C), which penetrate downward or sideward into the crystals and are filled with different minerals (mostly dolomite). Some gypsum crystals pre-sent thin micro-fractures that radiate from their limits
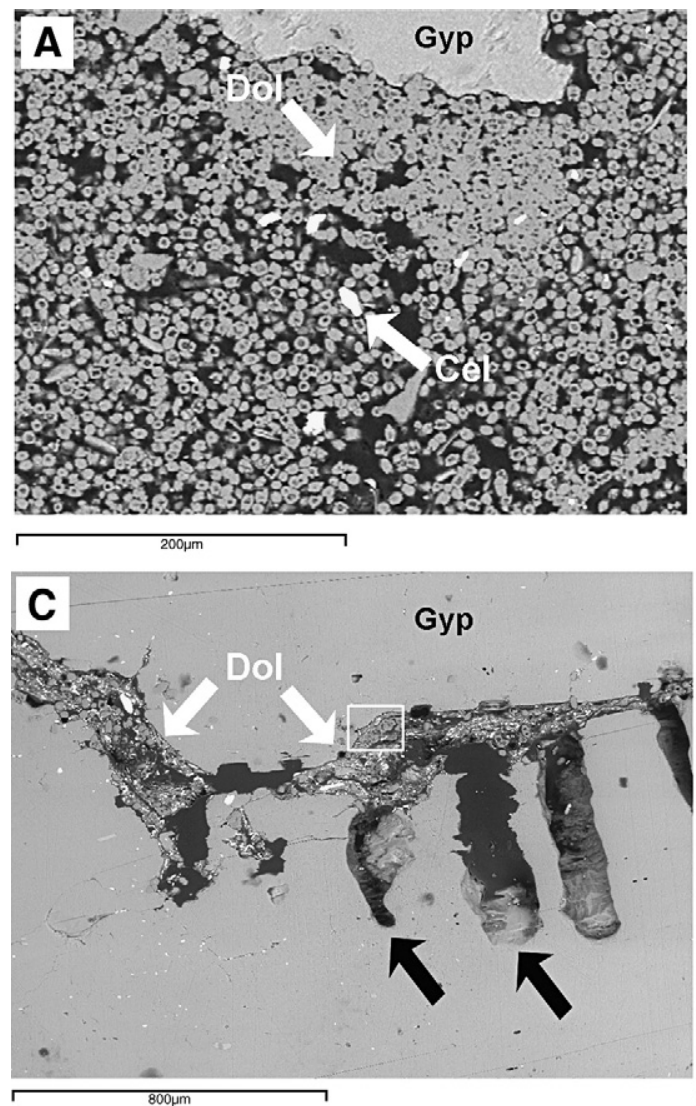

towards the interior of single grains, but no crosscutting inter-granular fractures are observed (Fig. 5C).

Within the gypsum abundant anhydrite prismatic crystals (10's microns in size) can be found (Fig. 12C), generally grouped in clusters and/or along planes of preferred orientation (twin or main cleavages). Isolated bi-pyramidal celestite crystals are also present, prefer-entially close to the subcrystal borders.

A detailed examination of the areas with dolomite using SEM imagery (Fig. 6A) showed a characteristic texture of round-shaped crystals with hollow cores, most between 5 and $25 \mu \mathrm{m}$ in size. A closest view of the crystals indicated a knobby surface but an irreg-ular empty space in the centre. Some of them showed coalescence and aggregation forming filament like structures (arrows in Fig. 6B). Celestite crystals were distributed in the gypsum deposits and concentrated in the areas with dolomite at the micro-dissolutional surfaces outlining the subcrystals (white arrows Fig. 6C)
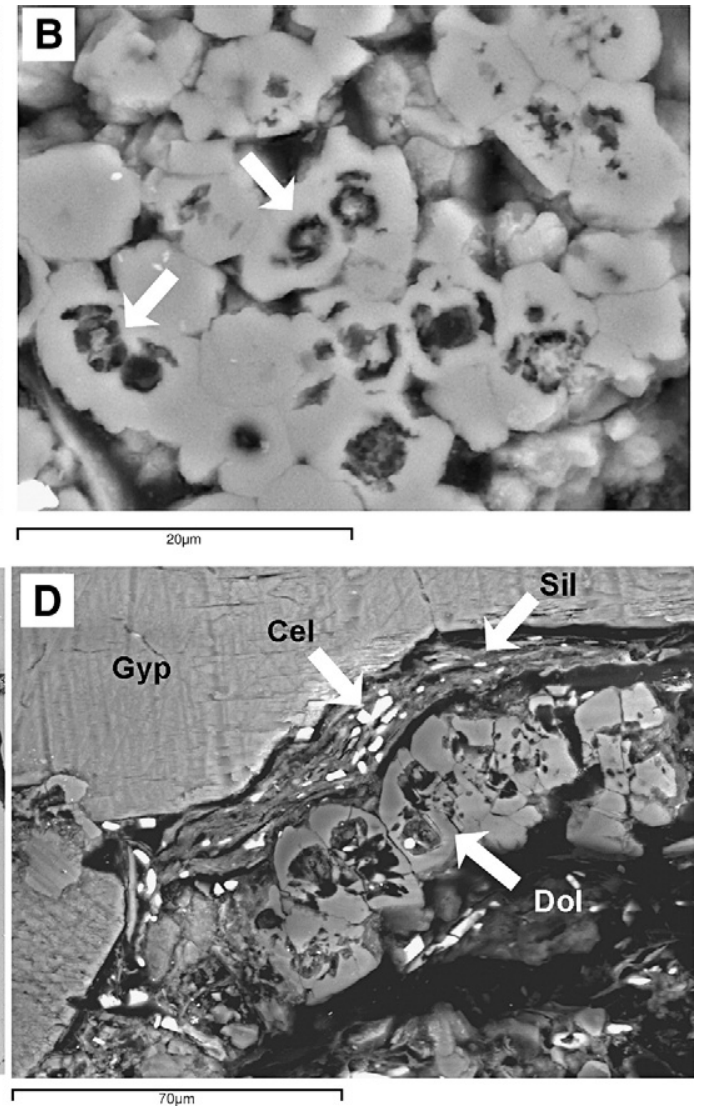

Fig. 6. SEM-BSE images of dolomite areas inside gypsum crystals. A. Aspect of dolomite and celestite precipitates inside gypsum crystals. B. Detail of the dolomite grains. Notice the voids and the filamentous aspect of some of them (arrows). C. Aspect of the surface of a gypsum subcrystal in contact with silicate and dolomite filling (white arrows). Notice the channels of dissolution (black arrows). D. Detail view of the dolomite and celestite crystals. The celestite crystals are related with the silicate filling in close contact with the surface of the gypsum crystals. Gyp= gypsum; Dol= dolomite $; \mathrm{Cel}=$ celestite; $\mathrm{Sil}=$ Silicates. 
and close to microtubes (black arrows Fig. 6C). Celestite crystals present inside gypsum samples had prismatic habits and very variable sizes $(2-200 \mu \mathrm{m})$ (Fig. 6D), though commonly the maximum ranged tens of mi-crons. A detail image showed that celestite was more frequently present in relation with dolomite crystals and silicate-rich areas ( $\mathrm{Si}$ and $\mathrm{Al}$ rich) (Figs. 6D and 9A).
The digital mapping distribution of $\mathrm{Sr}+\mathrm{S}, \mathrm{Al}, \mathrm{Si}, \mathrm{Ca}$ and $\mathrm{Mg}$ is shown in Fig. 7.

Epifluorescence microscopical examination of fresh samples showed the presence of living endolithic cyano-bacteria colonies inside the gypsum crystals (Fig. 8A). The same colonies were visualized with scanning elec-tron microscopy in backscattered mode (Fig. 8B). The
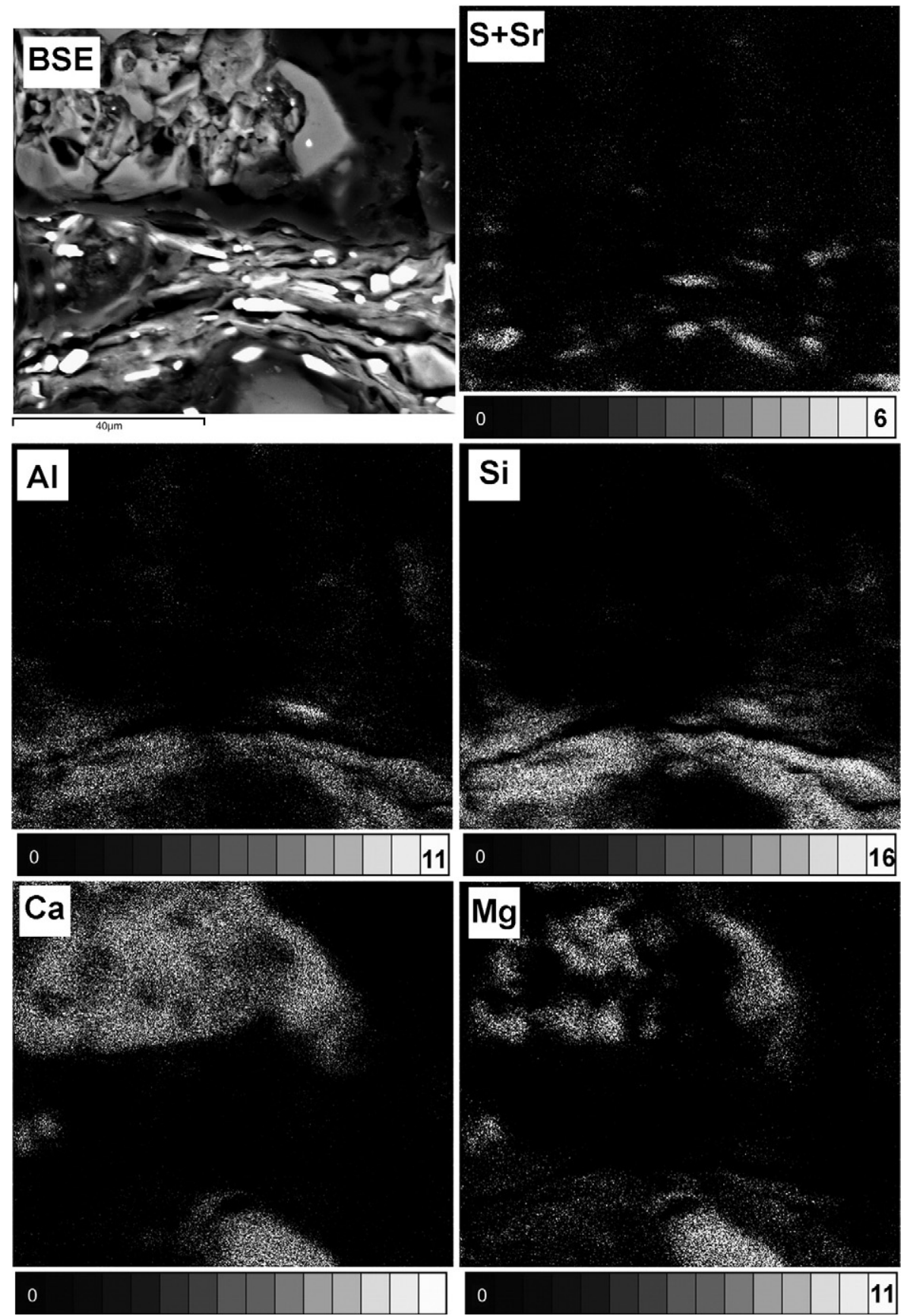

Fig. 7. SEM-BSE image and digital mapping distribution of $\mathrm{Sr}+\mathrm{S}, \mathrm{Al}, \mathrm{Si}, \mathrm{Ca}$ and $\mathrm{Mg}$ of the area marked with a square in Fig. $6 \mathrm{C}$. 

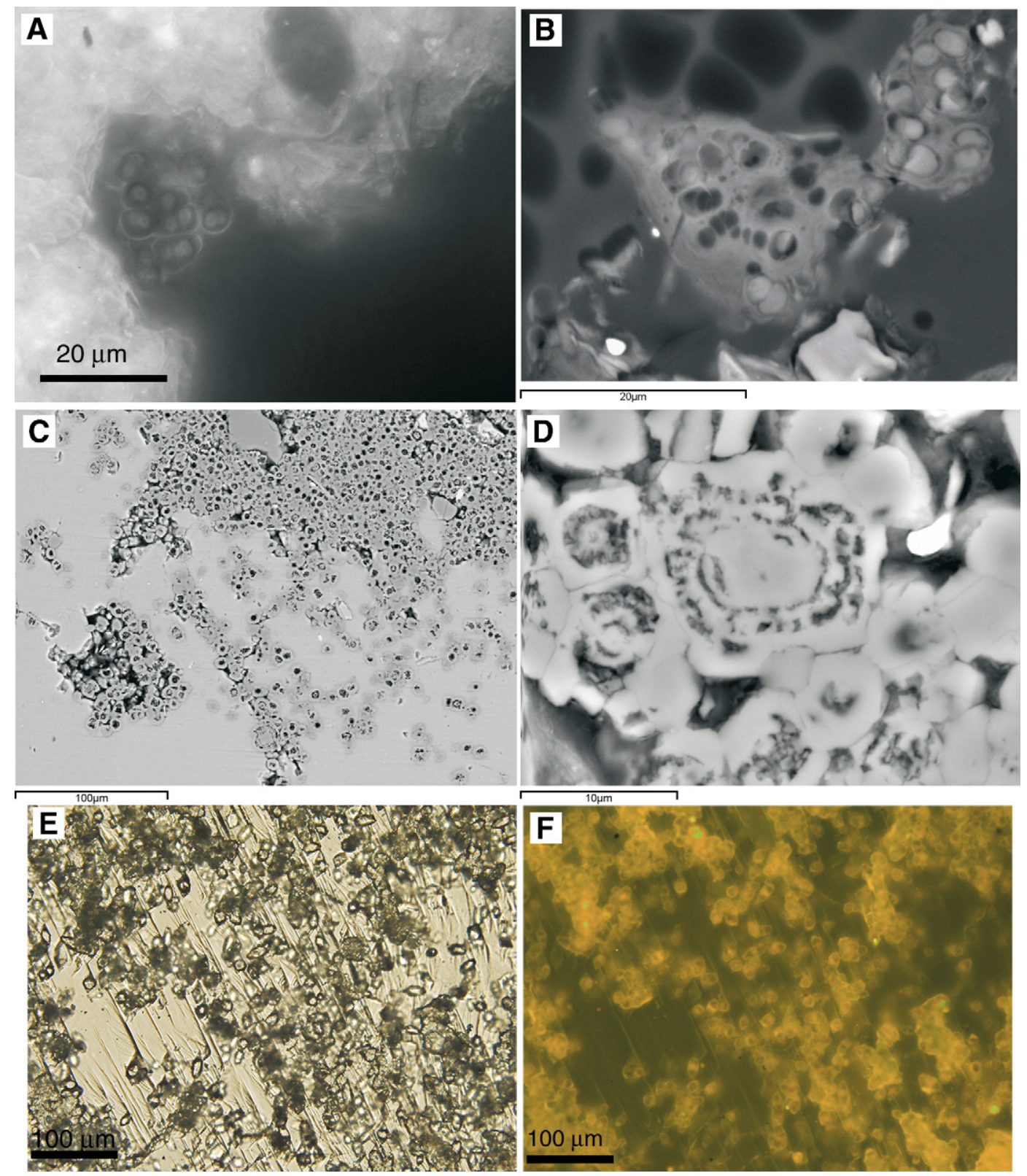

Fig. 8. A. Epifluorescence image of the endolithic cyanobacteria living in the gypsum crystals. B. SEM-BSE image of the living endolithic communities inside the gypsum crystals. C. SEM-BSE image of a general view of the dolomite distribution in the gypsum deposits. Notice the pitting effect and the distribution inside cavities of the dolomite granules and the similarities with Fig. 8A. D. A detail view of crosssections of dolomite grains. Notice concentric deposition around hollows and similarities with distribution of cell walls and extracellular polymeric substances between Fig. 8B and D. E. Photomicrograph of a thin section showing the distribution of the dolomite replacement. F. Epifluorescence image of the same area showed in E. Notice the fluorescent signal from the material surrounding the hollows.

distribution and morphological features of these modern communities (Fig. 8A) share striking similar features with the aggregates of dolomite granules and suggests that the nucleation of dolomite might be controlled by the presence of similar endolithic communities in the gypsum crystals (Fig. 8C).
The dolomite material is distributed indicating ir-regular dissolution associated with endolithic coloniza-tion of the gypsum deposits. The granulate dolomite precipitate showed a peculiar ultrastructure not related with a preferential dissolution of the interior and more related with a concentric growth (Fig. 8D). Optical and 
epifluorescence images of the dolomite crystals showed a clear fluorescence pattern associated with the carbonate (Fig. 8E and F).

Most of the dolomite granules present in the gypsum deposits showed empty interior hollows, which were outlined by the fluorescent carbonate material (Fig. 8F). However, only in scarce situations some occurrences of calcite cements inside and outside the dolomite granules have been observed (Fig. 9A and B). The distribution maps of the $\mathrm{Mg}$ and Ca-rich material indicate the association of both minerals (Fig. 9C and D). The presence of calcite as a cement indicates carbonate precipitation in areas with previous dolomite deposition suggesting dissolution/reprecipitation processes that took place under very restricted conditions as denotes the scarcity of these cements in the studied samples
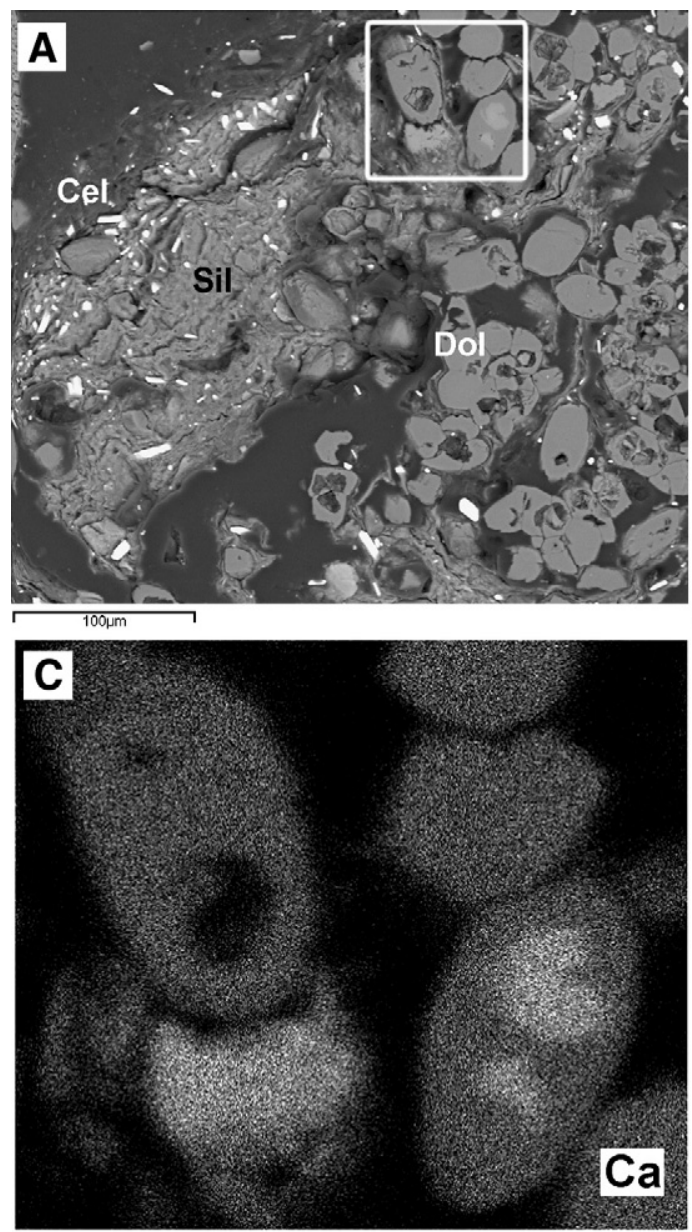

0
(Fig. 9A). The X-ray energy dispersive spectroscopic analysis of the precipitates indicated the presence of $\mathrm{Si}$, $\mathrm{Al}$ and $\mathrm{Fe}$ in the dolomite deposits. The $\mathrm{Mg}$ :Ca relation by EDS in the dolomite grains was around 0.48 (Fig. $10)$.

\subsection{Fluid inclusion analysis}

Fluid inclusions are very abundant in Christmas-tree gypsum formations. At least three fluid inclusion generations can be differentiated in the gypsum crystals. They are defined as primary, pseudo-secondary and tubular and can be differentiated in the studied samples on the basis of (1) distribution of inclusions' assemblages within crystals, (2) inclusions' shape and size, and (3) inclusions' content (Figs. 11 and 12).
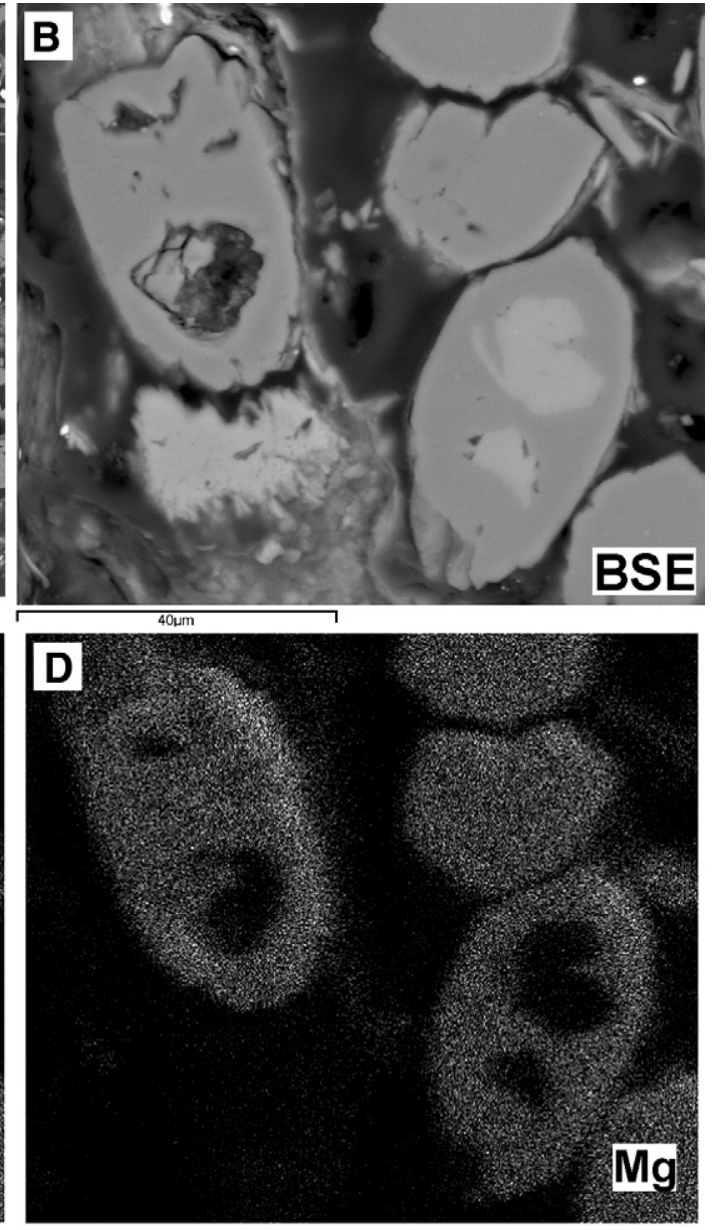

Fig. 9. SEM-BSE images of dolomite areas inside gypsum crystals. A. General view of the cavity with clays, celestite and dolomite crystals. Dol= dolomite; Sil= silicates; Cel= celestite. B. Detail image of the area marked with a square in A. C and D. EDS digital mapping distribution of Ca and $\mathrm{Mg}$ in the area showed in $\mathrm{B}$. 


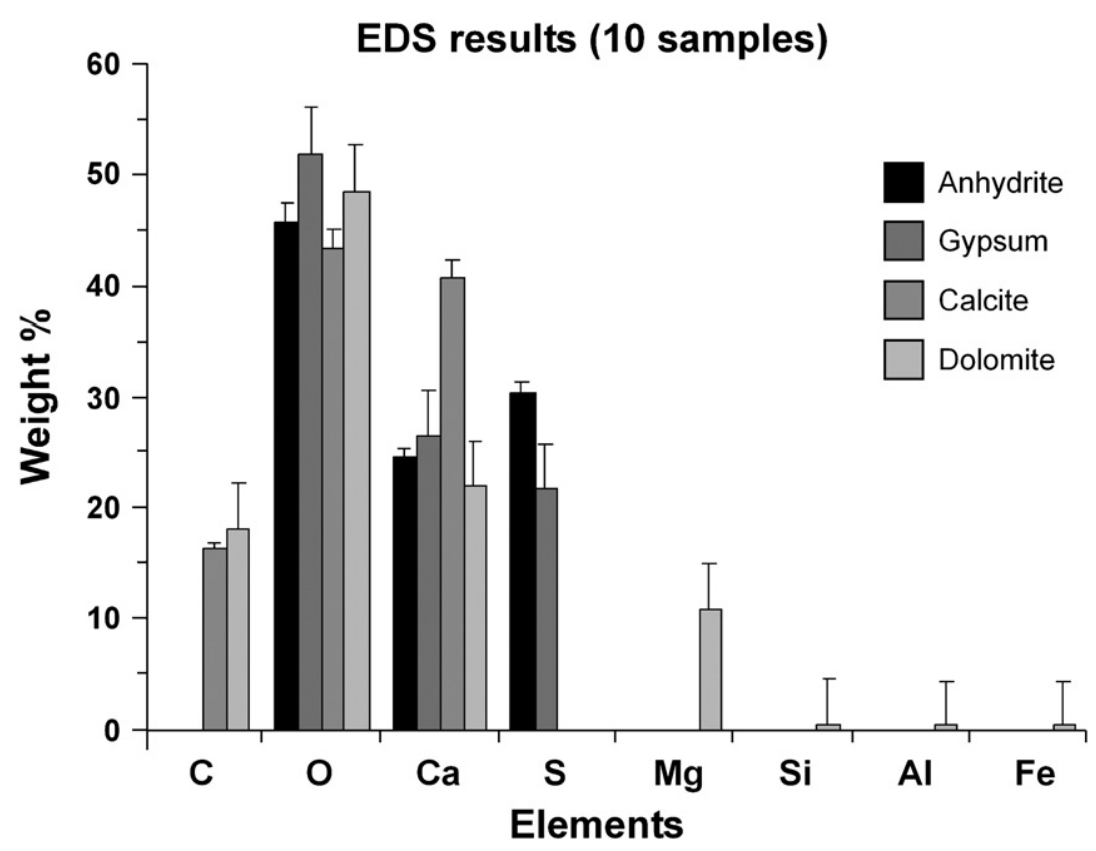

Fig. 10. Comparison of the elemental composition (EDS wt.\%) of dolomite and gypsum present in the samples with anhydrite and calcite standards.

\subsubsection{Primary inclusions}

The most numerous assemblages form big clusters in extensive zones that run parallel to the faster growth faces, this is, parallel to the $\{120\},(100)$ and $(010)-$ actually (020)- faces (Fig. 11). These inclusions have sizes from tens (some even $\mathrm{N} 100 \mu \mathrm{m}$ ) to a few microns

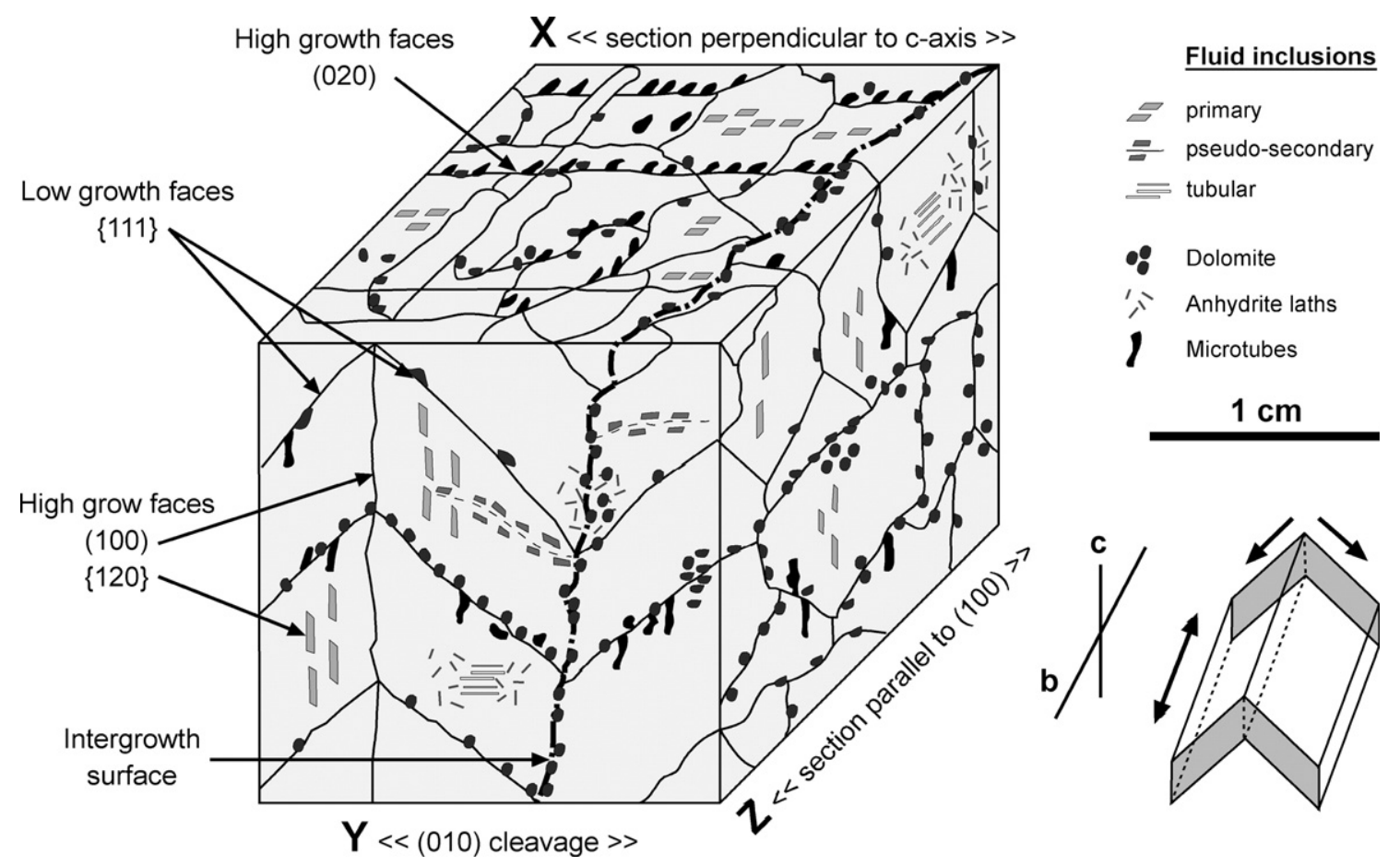

Fig. 11. 3D type sketch of a Christmas-tree gypsum sample, showing crystallography, textural features and the distribution of minerals and fluid inclusion types. Sketch on the right shows a single stage of crystal growth and the arrows indicate the faster growth directions. $\mathrm{b}$ and $\mathrm{c}$ reflect the crystallographic axes. 


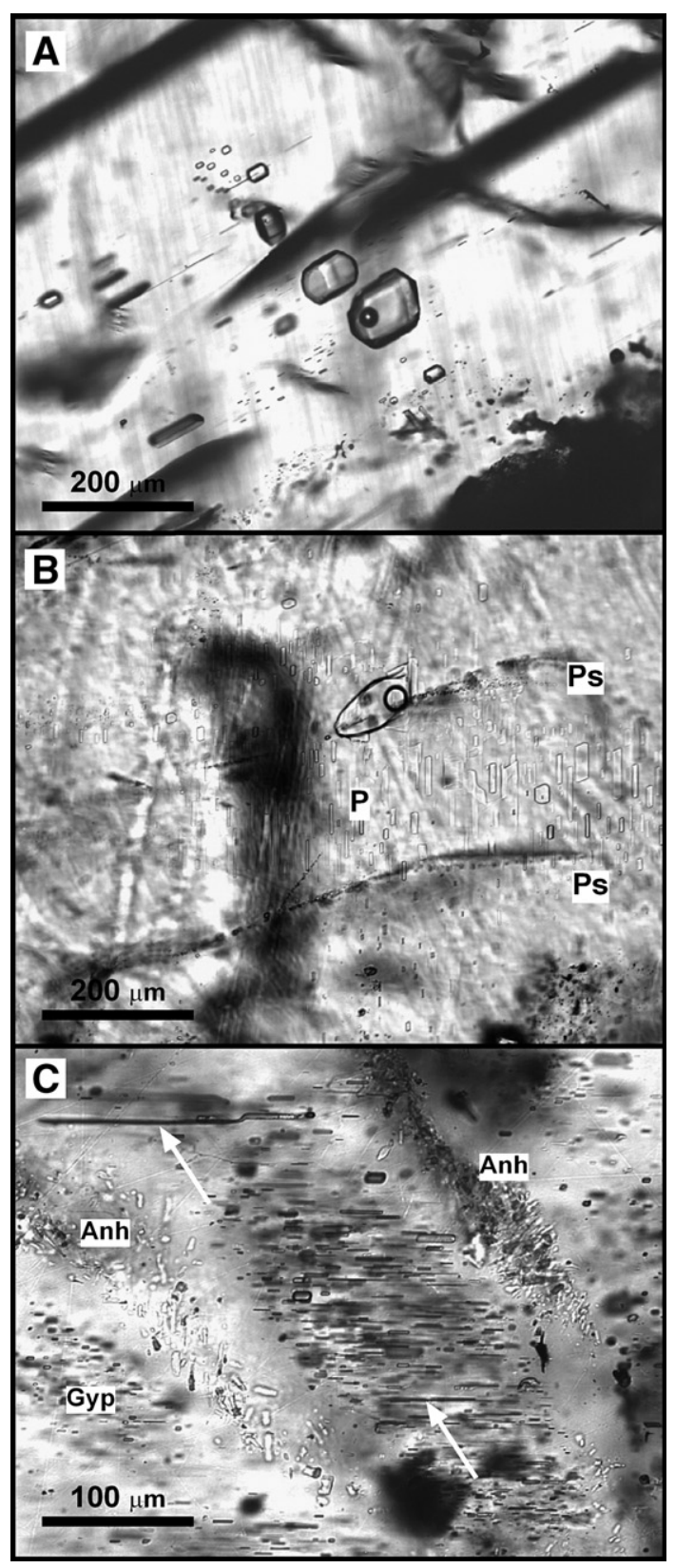

Fig. 12. Photomicrographs illustrating the three types of fluid inclusions present in Christmas-tree gypsum (Gyp). A. Primary inclusions. Note the euhedral shapes and different sizes. B. Pseudo-secondary inclusions. Two thin trails (Ps) cross-cut a cluster of primary inclusions (P). C. Tubular inclusions (arrows). Cluster delimited by planes formed by anhydrite (Anh) crystals.

(Fig. 12A). The long sides of these micro-cavities are oriented parallel to the c-axis, as well. These inclusions show euhedral shapes, rectangular to pseudo-hexagonal (according to the plane of view), reflecting the host- mineral crystallographic system (Figs. 12A and 13). The assemblages formed along the slow growth faces $\{\bar{I} 11\}$ - contain inclusions which present a dirtier, more irregular aspect and have smaller sizes.

At room temperature both groups consist of domi-nantly monophase liquid inclusions (L) (Fig. 13A), although a significant amount of individuals also present a bubble. These bubbles do not contain a vapour phase and they are entirely an artefact product of inclusion stretching ( $\mathrm{V}$ in Fig. 13B). Many inclusions contain clusters of rounded greenish crystals $(\mathrm{L}+\mathrm{S})$, gener-ally attached to the inclusions' walls. Most of them, attending to their optical properties, resemble anhydrite (Fig. 13B and C).The liquid phase represents an aqueous solution of low to moderate salinity. During cooling runs nucleation temperature is more or less constant at around $-40{ }^{\circ} \mathrm{C}$ but, despite repeated efforts to nucleate salt hydrates by temperature cycling, only final ice melting temperatures (freezing point depression) could be determined. They range from -6.3 to $-1.1{ }^{\circ} \mathrm{C}$ (Fig. 14A). Although $\mathrm{CaSO}_{4}$ must be the most abundant dissolved salt, salinities have been estimated as equivalent in total weight $\%$ of $\mathrm{NaCl}$ (eq. wt. $\% \mathrm{NaCl}$ ), according to the formula of Bodnar (1992) for the $\mathrm{H}_{2} \mathrm{O}-\mathrm{NaCl}$ system we obtained values range from 9 to 2 eq. wt. $\% \mathrm{NaCl}$ (Fig. 14C).

\subsubsection{Pseudo-secondary inclusions}

These inclusions are grouped in discrete, well defined linear to curved thin trails (micro-fractures), starting at grain boundaries and always restricted to single crystals (Fig. 11). The trails contain subhedral, rounded, small $(20$ to $\mathrm{b} 2 \mu \mathrm{m})$ and monophase all $\mathrm{L}$ (few $\mathrm{L}+\mathrm{V}$ ) inclusions (Fig. 12B). From the aqueous phase, obtained total ice melting temperatures and derived salinities (see above) range from -5.5 to $-1.5^{\circ}$ $\mathrm{C}$ and from 8.5 to 2.5 eq. wt.\% $\mathrm{NaCl}$, respectively (Fig. 14B a n d D).

\subsubsection{Tubular inclusions}

These inclusions are restricted within areas delimited by inclusion-free crystalline gypsum and planar clusters of disordered anhydrite crystals (Fig. 11 and arrows Fig. 12C). They resemble reported shapes of primary inclusions in anhydrite (Goldstein and Reynolds, 1994), having needle-like or tubular shapes and their sizes in the two short dimensions are 1-3 $\mu \mathrm{m}$. No ice nucleation or melting is observed, probably due to the small inclusion sizes, which may hinder nucleation. Detailed observations suggest that many of them are empty. 


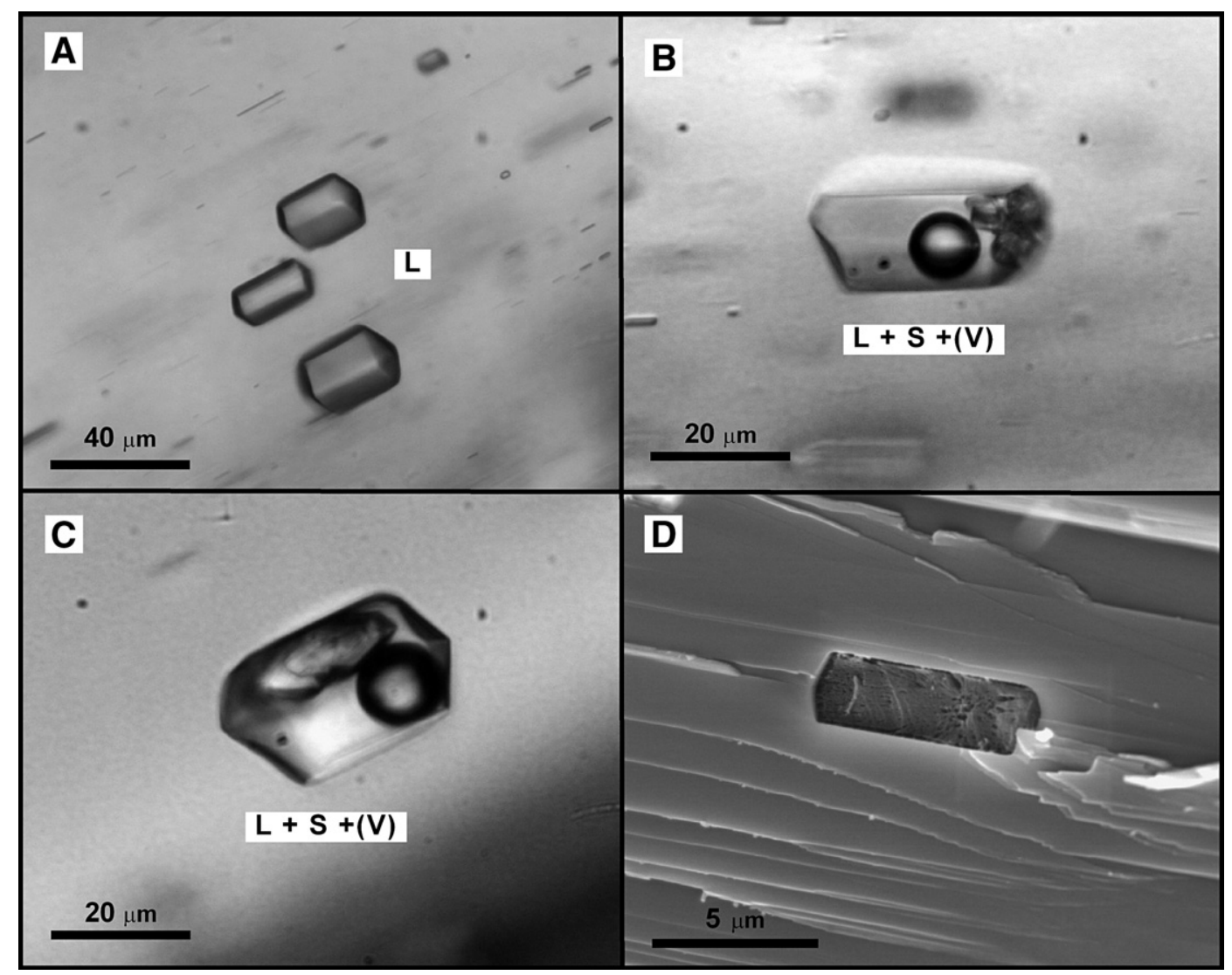

Fig. 13. Photomicrographs illustrating different types of primary fluid inclusions in Christmas-tree gypsum. A. Monophase liquid inclusions (L). B and C. Primary inclusion with bubbles (V) and clusters of rounded crystals (S). D. Low Temperature Scanning Electron micrograph of a fluid inclusion with frozen content.

\subsection{Low Temperature Scanning Electron}

Microscopy with Energy Dispersive Spectroscopy

No valid semi-quantitative cation concentrations could be obtained with the Cryo-SEM technique in the liquid phase of the fluid inclusions in the Christmastree gypsum. This was mainly due to the low solute concentration (salinity) in the fluid present within the inclusions, which often hindered the nucleation of a congruent, uniform frozen mass. Many inclusions were emptied during the fracturing process and liquid or partially frozen samples were not suitable for analysis. The frozen inclusions showed both smoothed and speckled frozen mass mor-phologies (Fig. 13D). The latter ones seemed to give better detection results, and in addition to $\mathrm{Ca}^{2+}$, traces of $\mathrm{Na}$ ${ }^{+} \mathrm{Mg}^{2+}$ and $\mathrm{K}^{+}$were consistently detected within the frozen dilute brine fluid in all the analysed inclusions. However, solute concentrations were always below the detection limits or smaller that the minimum accepted measurement error, which is even more obvious when the background effect of the host mineral $\left(\mathrm{CaSO}_{4}\right)$ is taken into account.

\section{Discussion}

\subsection{Fluid conditions and gypsum growth sequence}

Primary inclusions in Christmas-tree gypsum arrange parallel to faster growth faces in contrast with the general pattern of arrangement of primary fluid inclusion in gypsum along the (001) plane or normal to the (103) plane, reported by Goldstein and Reynolds (1994). I n addition, primary inclusions in Christmas-tree gypsum show morphological differences with those depicted by Goldstein and Reynolds (1994), because spike-like shapes have not been observed in the studied samples.

Data obtained from primary fluid inclusions in the Christmas-tree gypsum formation indicate that this min-eral precipitated from an aqueous fluid (lake water) of low to moderate total salinity (20 to $90 \mathrm{~g} / \mathrm{L}$ ). These con-centrations indicate that lake water salinity fluctuated between these concentrations and was about $50 \mathrm{~g} / \mathrm{L}$ (weighed average), while gypsum crystals were growing. This agrees with values measured from actual continental 
A

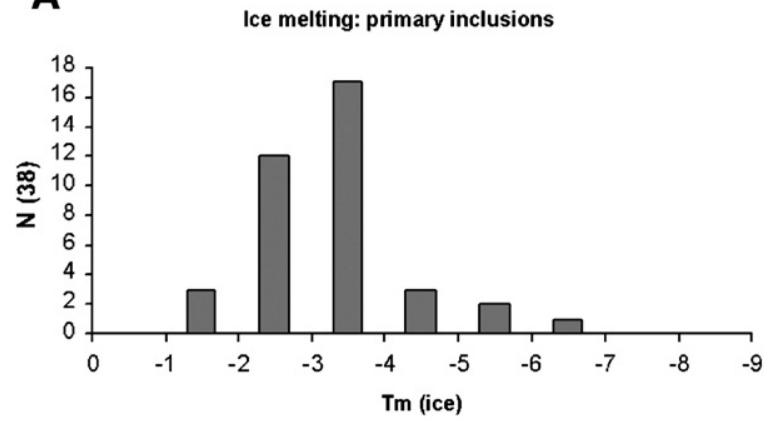

B

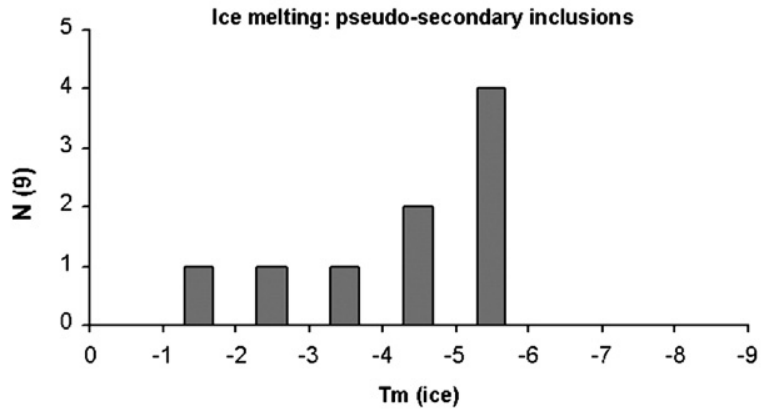

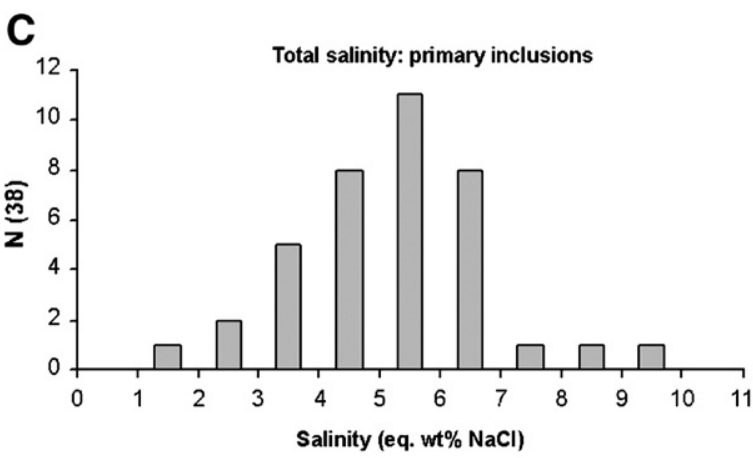

D

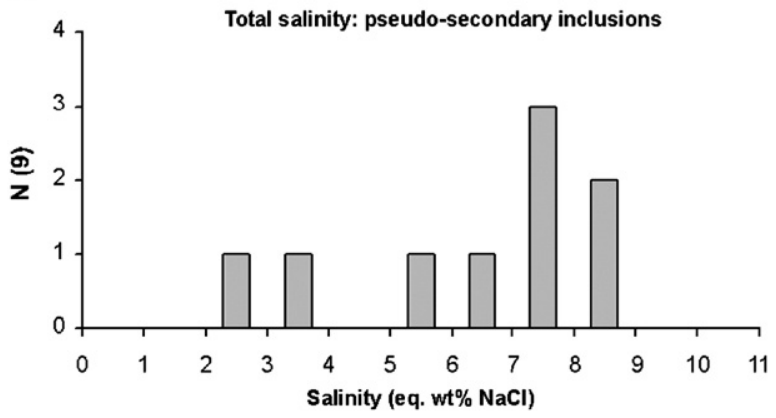

Fig. 14. A-B. Frequency-phase final ice melting temperature histograms (in ${ }^{\circ} \mathrm{C}$ ) of primary and secondary fluid inclusions in Christmas-tree gypsum, respectively. C-D. Frequency-phase total salinity histograms (given as eq. wt.\% $\mathrm{NaCl}$ ), of primary and secondary fluid inclusions, respectively. Based on the preceding data.

saline lake settings where gypsum precipitation takes place from brines enriched in $\mathrm{CaSO}_{3}$ (Warren, 1999). By contrast, modern selenite gypsum that precipitates from marine water in coastal saltworks needs salinities of $250-300 \mathrm{~g} / \mathrm{L}$ (Ortí-Cabo et al., 1984).

Pseudo-secondary inclusions were formed along micro-fractures due to crystallization pressure and com-petitive growth of gypsum crystals. They content fluids with the same range of salinities as the primary ones ( 2.5 to 8.5 eq. wt. $\% \mathrm{NaCl}$ ), though clearly shifted towards saltier values, usually more than 5 eq. wt.\%. This fluid could represent interstitial lake brine in contact with gypsum, slightly enriched in salts as crystal formation proceeded (Fig. 15A). Similar range of var-iation in the total salinity respect to primary and pseudosecondary inclusions, $2-6$ eq. wt. $\% \mathrm{NaCl}$, has been recorded from fluid inclusions in Miocene selenite gypsum formed from mixed seawaternonmarine waters in Crimea (Peryt et al., 2004).

Though no quantitative concentration values for solute species could be determined, EDS measurements of frozen inclusions fluids point at least to the presence of $\mathrm{NaCl}, \mathrm{MgCl}_{2}$ and, possibly, $\mathrm{KCl}$ in the aqueous brine, besides $\mathrm{CaSO}_{4}$. No evidence for the presence of gas or hydrocarbon phases has been found. These results (low lake water total salinities and minimal concentration of chlorides) confirm previous interpretations. This type of continental brine fits the type II evolutionary path defined by Eugster and Hardie (1978). According to Rodríguez-Aranda et al. (1995a), the uncommon crystalline pattern of those gypsums was controlled by the specific composition of the brines, deduced analysing the rocks of the source area (Altomira Range). This is now confirmed by the fact that proposed faster crys-tal growth faces do contain most of the fluid inclusion assemblages. The rock formations surrounding the Miocene lakes at Driebes (and at present day) were Mesozoic and Palaeogene limestones, dolostones and gypsums. Therefore, the composition of the lake brines was controlled by the carbonate and sulphate rocks source area from which the lake-feeding water flows or inflows circulated; being $\mathrm{Ca}-\mathrm{Mg}-\mathrm{Na}-\mathrm{SO}_{4}-\mathrm{HCO}_{3}-\mathrm{Cl}$ the dominating dissolved ions (Fig. 15A). The waters initially had $\mathrm{HCO}_{3}{ }^{-} \ll \mathrm{Ca}^{2+}+\mathrm{Mg}^{2+}, \mathrm{C} \mathrm{a}{ }^{2+} \gg \mathrm{Mg}^{2+}$ and $\mathrm{Ca}^{2+} \mathrm{NSO}_{4}{ }^{-2}$, evolving after precipitation of dolomite and gypsum to $\mathrm{Ca}-\mathrm{Na}-\mathrm{Cl}$ brine (Fig. 15A).

Occasionally, the saline lake experienced dry stages that could led to the early diagenetic replacement of gyp-sum by anhydrite (Fig. 15C). Burial conditions reached by the gypsum deposits, less than 100 m (Rodríguez-Aranda 
A

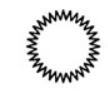

$\left.\begin{array}{|c|c|}\mathrm{H}_{2} \mathrm{O} & \mathrm{H}_{2} \mathrm{O} \\ \mathrm{Ca}^{2+}, \mathrm{SO}_{4}^{2+}, \mathrm{Sr}^{2+}, \mathrm{HCO}_{3}{ }^{-} & \ll\left(\mathrm{Mg}^{2+}, \mathrm{K}^{+}, \mathrm{Na}^{+}, \mathrm{Cl}\right)\end{array}\right\}$

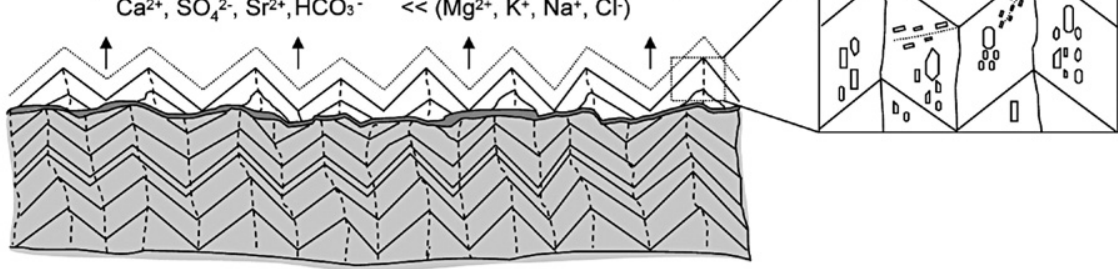

B
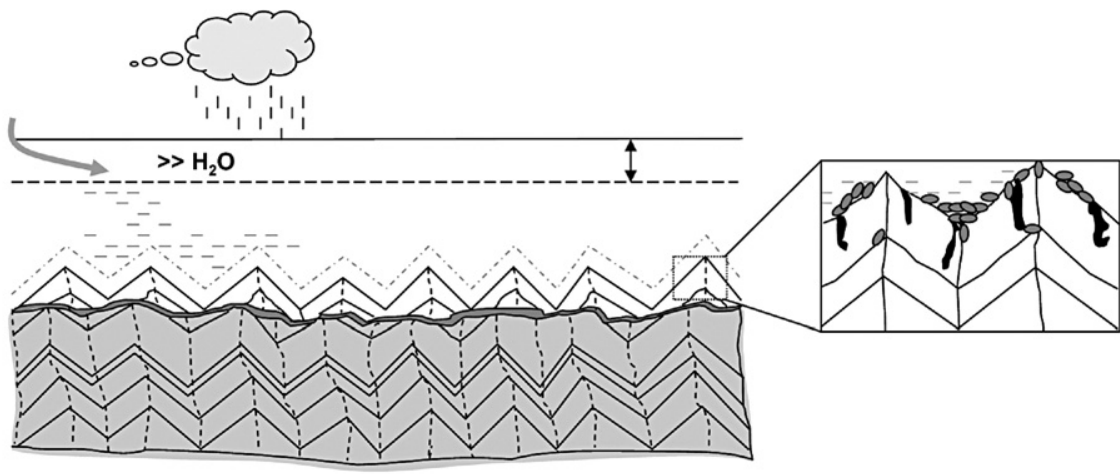

C
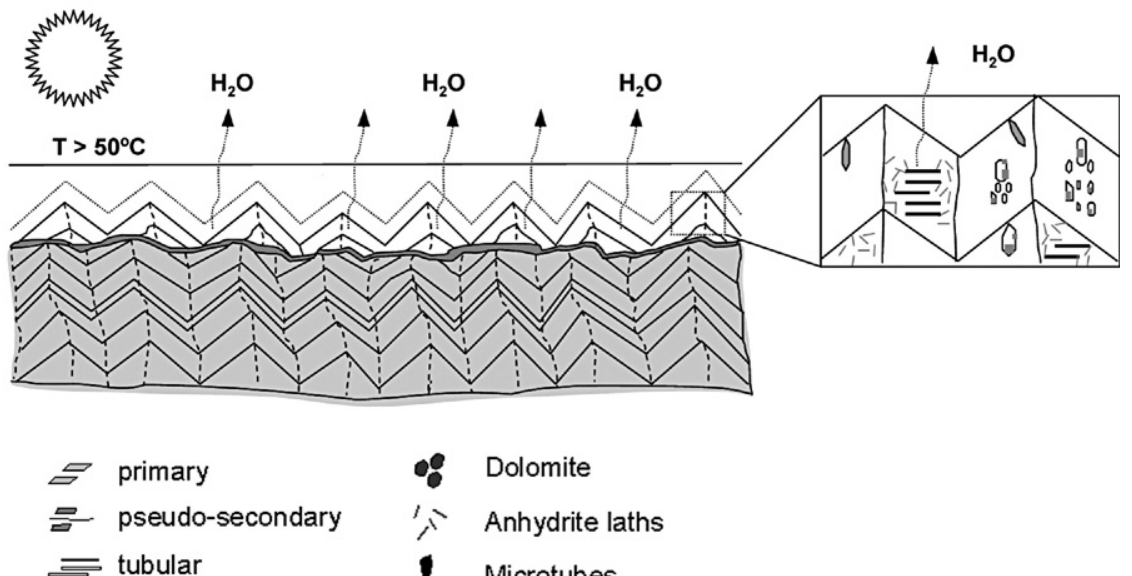

- Dolomite

'is Anhydrite laths

1 Microtubes

Fig. 15. Sketch diagrams illustrating the relation of the Christmas-tree gypsum features analysed in the present work with the presumed seasonal lake water conditions under which they formed. The dark grey band represents a dolomite deposit (as in Fig. 3), separating actual gypsum growth/precipitation (non-coloured) from a previously formed gypsum bed (light grey). A. Normal gypsum precipitation conditions, with lake water salinities below $90 \mathrm{~g} / \mathrm{l}$. B. Lake brine freshening due to input of rain and/or seasonal water flow. Most detrital particles enter the lake during this period and dolomite precipitation took place. C. Lake desiccation stages. Gypsum growth ends and dehydration reactions take place, forming anhydrite.

et al., 1995a), are not enough to cause the transforma-tion of gypsum to anhydrite (Warren, 1999). Then, the observed partial transformation of gypsum to anhydrite must have taken place as a result of early diagenetic dehydration processes (Fig. 15C). During this transfor-mation, sets of tubular inclusions were formed within the gypsum.

\subsection{Gypsum growth and dolomite precipitation}

In the basin, mudstones and marls were deposited in saline mudflat subenvironments whereas gypsum and dolomite formed in a saline lake setting. Gypsum crystals grew to form a crust in stable bottom waters in periods of brine concentration (Fig. 15A). The growth 
was regularly interrupted in concurrence with brine freshening (Fig. 15B). The seasonal character of the dilution event, probably correlate with the input of meteoric water to the lake, as suggested by the uniformity in the spacing of the vertically stacked subcrystals of gypsum. In addition, isotope analyses of the dolomite samples yielded $\delta{ }^{18} \mathrm{O}$-values ranging from -7.79 to $-2.65 \%$ PDB, which suggest the mineral precipitated from relative diluted waters (Sanz-Montero et al., 2003). The faces forming the twin re-entrant angle of the gypsum, that is $\{\overline{\mathrm{I}} 11\}$ bipyramids, are characterized by low growth rates and display micro-dissolution features as well as dolomite. The slow growth of those faces enable sedimentary particles and organic matter to accumulate on them. Thus, while the gypsum grew the subcrystal limits developed a microenvironment inside the crystal leading to the formation of dolomite.

In actively forming evaporitic deposits the endolithic microbial community can became very diverse and form laminated microbial mats (Oren et al., 1995; Gerdes et al., 2000). In contrast, sedimentary gypsum deposits are colonized by endolithic microbial communities (Golubic et al., 1981) that are involved in processes of bioweathering, dissolving and producing the fragmentation of the crystals during colonization of the surfaces (Souza-Egipsy et al., 2002). The same type of endolithic communities might have been able to colonize the gypsum evaporite sediments of the Madrid basin, dwelling between the gypsum crystals while the growth of the surfaces was regularly interrupted (Fig. 15B).

The dolomite crystals developed in the Miocene Driebes formation seem to be related with the biomineralization of endolithic cyanobacterial communities after the precipitation of gypsum crystals. The role of microbial mediation in dolomite formation has been emphasized because chemical conditions of the waters alone could not be responsible of the mineral precipitation. The bacterial cell wall and extracellular polymeric substances around the cells acted as nuclei for precipitation of dolomite. Similar microcrystalline dolomite fabric have been found and interpreted to have formed in shallow, hypersaline and anoxic waters (Rao et al., 2003). Recently, Sanz-Montero et al. (in review) suggest that highly structured substances embedding coccoid microbial forms may have templated dolomite nucleation in Miocene lacustrine dolomite-silica microbialites of the Duero Basin. The embedding substances, on which dolomite crystals rest, are mineralized in opal and exhibit a reticular arrangement that seems to match the lattice geometry of dolomite.

The ability of cyanobacteria to alter geochemistry of its environment and therefore to influence the mineral phase has been shown under laboratory conditions
(Thompson and Ferris, 1990; Schultze-Lam and Beveridge, 1994). Laboratory experiments have shown microbial mediation as a possible mechanisms for dolomite formation at low temperatures (Vasconcelos et al., 1995; Warthmann et al., 2005; Wright and Wacey, 2005). However, several aspects should be taken into account in the resulting carbonate precipitate around microbial communities: the physicochemical environment; the physico- and chemical properties of potential nucleation sites and the physiological activities of microorganisms (Arp et al., 1999a,b, 2001; Dupraz et al., 2004). As a result of the combination of these factors several ways of precipitation have been described (Dupraz and Visscher, 2005).

Recent experiments have demonstrated the potential of cyanobacteria to precipitate calcite and provide some evidence that the cell walls of the cyanobacteria acted as a substrate of nucleation of $\mathrm{CaCO}_{3}$ (Dittrich et al., 2003). The first step of this nucleation process is the increase of surface charge of the cells after $\mathrm{Ca}^{2+}$ addition, indicating Ca-adsorption onto the cell walls (Dittrich and Sibler, 2003). In contrast an increase of $\mathrm{Mg}^{2+}$ adsorption in the first step of mineral nucleation has also been indicated by other authors (Verrecchia et al., 1995; Braissant et al., 2003; van Lith et al., 2003), and in natural samples of cyanobacteria in lakes (Thompson and Ferris, 1990) and endolithic communities (Léveillé et al., 2002; Souza-Egipsy et al., 2005). Both $\mathrm{Mg}^{2+}$ and $\mathrm{Ca}^{2+}$ are the main ions bound to the outer membrane of gram-negative bacteria (Coughlin et al., 1983). The ions adsorbed onto bacterial surf-aces can induce the precipitation of finegrained cal-cium carbonates by the complexation of counter ions (Schultze-Lam et al., 1996; Fortin et al., 1997; Douglas and Beveridge, 1998). The same process has been found to occur in the bacterial cell surface of sulphate-reducing bacteria (van Lith et al., 2002, 2003; Aloisi et al., 2006). Then, formation of dolomite around the cells can be explained as a biomediation process related to the organic matrix of the cell wall and ex-tracellular polymeric substances in combination with the conditions of the brine in the environment (Dupraz et al., 2004; Dupraz and Visscher, 2005; Aloisi et al.,

2006).

The cell walls of bacteria and the extracellular polymeric substances have a strong affinity for $\mathrm{Ca}$ and $\mathrm{Mg}$ cations under saline conditions (Beveridge and Fyfe, 1985; Beveridge, 1989; Souza-Egipsy et al., 2005), and the amount of ions binding to the organic matrix will depend on the surrounding conditions (Dittrich et al., 2003). Depending on their acidity and stereochemical arrangement, acidic macromolecules forming part of the 
extracellular polymeric substances are also considered to control growth and shape of the biominerals (Wheeler and Sikes, 1984; Addadi and Weiner, 1985; Addadi et al., 1989; Braissant et al., 2003). Thus, an initial extracellular formation of calcite onto the cell walls and the extracellular polymeric substances will deplete the $\mathrm{Ca}^{2}$ + content of any brine, subsequent carbonate precipitation from a saline water will have a higher $\mathrm{Mg} / \mathrm{Ca}$ ratio and tend to be dominated by high $\mathrm{Mg}$ calcite, aragonite, magnesite or dolomite (Warren, 1999). Thus, the reactivity of the organic matrix around the cells might be responsible of the induced formation of dolomite.

Studies from natural samples have shown that microenvironmental conditions may overcome the kinetic barrier for dolomite precipitation at Earth-surface conditions and produce non-stoichiometric dolomite that later became limpid stoichiometric dolomite with well-developed rhombohedral faces (Machel and Mountjoy, 1986; Rodríguez-Navarro et al., 1997; Rao et al., 2003). The role of the cell wall nucleation processes in the formation of the dolomite precipitates comes from applying in situ study of the samples. The texture of the dolomite crystals and the interior voids indicated a clear relation with the structure of the living endolithic communities of micro-organisms colonizing modern gypsum deposits.

\section{Conclusions}

The distribution of fluid inclusions in a primary selenite

gypsum has been described. The fluid inclusion were distributed preferentially in the planes of faster growth and at their intersections. Three fluid inclusion generations could be differentiated in the gypsum crystals. They are defined as primary, pseudo-secondary and tubular and can be differentiated by distribution within crystals, shape and size, and content. The results from microthermometry of primary inclusions provide evidences on the moderate salinity of the lacustrine brine (between 20 and $90 \mathrm{~g} / \mathrm{L} \mathrm{NaCl}$ ) during Christmas-tree gypsum formation.

Ultrastructural studies of dolomite formation in the gypsum crystals indicated a biological mediation in the process as a consequence of microbial colonization of the gypsum deposits during periodical gypsum growth interruptions. A multidisciplinary approach is needed when assessing geological processes where biological implications are found.

\section{Acknowledgments}

Thanks are due to F. Pinto who helped with Cryo-SEM at the Centro de Ciencias Medioambientales (CSIC) and to M. Fernández who helped with the XRD analysis at the Centro de Astrobiología (CSIC-INTA). Thanks are due to two anonymous reviewers for their valuable comments and suggestions. This work was funded by the Proyecto de la Comunidad Autónoma de Madrid GR/AMB/0603/ 2004, and the Centro de Astrobiología (CSIC-INTA). Work by V. S-E was funded by Programa Ramón y Cajal, Ministerio de Educación y Cultura, Spain.

\section{References}

Addadi, L., Weiner, S., 1985. Interactions between Acidic Proteins and Crystals-Stereochemical Requirements in Biomineralization. Proceedings of the National Academy of Sciences of the United States of America 82 (12), 4110-4114.

Addadi, L., Berman, A., Oldak, J.M., Weiner, S., 1989. Structural and stereochemical relations between acidic macromolecules of organic matrices and crystals. Connective Tissue Research 21 (1-4), $457-465$.

Aloisi, G., Gloter, A., Krüger, M., Wallmann, K., Guyot, F., Zuddas, P., 2006. Nucleation of calcium carbonate on bacterial nanoglobules. Geology 34, 1017-1020.

Arp, G., Reimer, A., Reitner, J., 1999a. Calcification in cyanobacterial biofilms of alkaline salt lakes. European Journal of Phycology 34, 393 403.

Arp, G., Thiel, V., Reimer, A., Michaelis, W., Reitner, J., 1999b. Biofilm exopolymers control microbialite formation at thermal springs discharging into the alkaline Pyramid Lake, Nevada, USA. Sedimentary Geology 126, 159-176.

Arp, G., Reimer, A., Reitner, J., 2001. Photosynthesis-induced biofilm calcification and calcium concentrations in Phanerozoic oceans. Science 292, 1701-1704.

Ascaso, C., Wierzchos, J., 1994. Structural aspects of the lichen-rock interface using backscattered electron imaging. Botanica Acta 107, 251256.

Ayora, C., Fontarnau, R., 1990. X-ray microanalysis of frozen inclusions at $-140^{\circ} \mathrm{C}$. Chemical Geology $89,135-148$.

Ayora, C., Garcia-Veigas, J., Pueyo, J.J., 1994. X-ray microanalysis of fluid inclusions and its application to the geochemical modelling of evaporite basins. Geochimica et Cosmochimica Acta 58, 43-55.

Bathurst, R.G.C., 1975. Carbonate Sediments and their Diagenesis. Developments in Sedimentology, vol. 12. Elsevier, Amsterdam.

Benzerara, K., Yoon, T.H., Tyliszczak, T., Constantz, B., Spormann, A.M., Brown Jr., G.R., 2004. Scanning transmission X-ray microscopy study of microbial calcification. Geobiology 2, 249-259.

Beveridge, T.J., 1989. Role of cellular design in bacterial metal accumulation and mineralization. Annual Review of Microbiology 43, $147-171$.

Beveridge, T.J., Fyfe, W.S., 1985. Metal fixation by bacterial cell walls. Canadian Journal of Earth Sciences 22, 1893-1898. Bodnar, R.J.,

1992. Revised equation and table for freezing point depressions of $\mathrm{H}_{2} \mathrm{O}$-salt fluid inclusions. PACROFI IV Fourth Biennial Pan-American Conference on Research on Fluid Inclu-sions, Lake Arrowhead, California, pp. 108-111.

Bosak, T., Newman, D., 2003. Microbial nucleation of calcium carbonate in the Precambrian. Geology 31, 577-580.

Braissant, O., Cailleau, G., Dupraz, C., Verrecchia, E.P., 2003. Bacterially induced mineralization of calcium carbonate in terrestrial environments: the role of exopolysaccharides and amino acids. Journal of Sedimentary Research 73, 485-490. 
Calvo, J.P., Ordóñez, S., García del Cura, M.A., Hoyos, M., AlonsoZarza, A.M., Sanz-Montero, M.E., Rodríguez-Aranda, J.P., 1989. Sedimentología de los complejos lacustres miocenos de la cuenca de Madrid. Acta Geológica Hispánica 24, 281-298.

Corzo, A., Luzon, A., van Bergeijk, S.A., Mata, P., García de Lomas, J., 2005. Carbonate mineralogy along a biogeochemical gradient in recent lacustrine sediments of Gallocanta Lake (Spain). Geomi-crobiology Journal 22, 283-298.

Coughlin, R.T., Tonsager, S., McGroarty, E.J., 1983. Quantitation of metal cations bound to membranes and extracted lipopolysaccharide of Escherichia coli. Biochemistry 22, 2002-2007.

Dittrich, M., Sibler, S., 2003. Cell surface groups of two picocyano-

bacteria strains studied by zeta potential investigations, potentio-metric titration, and infrared spectroscopy. Journal of Colloid and Interface Science $286,487-495$.

Dittrich, M., Muller, B., Mavrocodatos, D., Wehrli, B., 2003. Induced calcite precipitation by cyanobacterium Synechococcus. Acta Hydrochimica et Hydrobiologica 31, 162-169.

Dittrich, M., Kurz, P., Wehrli, B., 2004. The role of autotrophic picocyanobacteria in calcite precipitation in an oligotrophic lake. Geomicrobiology Journal 21, 45-53.

Douglas, S., Beveridge, T.J., 1998. Mineral formation by bacteria in natural microbial communities. FEMS Microbial Ecology 26, 79-88.

Dupraz, C., Visscher, P.T., 2005. Microbial lithification in marine stromatolite and hypersaline mats. Trends in Microbiology 13, 429438.

Dupraz, C., Visscher, P.T., Baumgartner, L.K., Reid, R.P., 2004 Microbe-mineral interactions: early carbonate precipitation in hypersaline lake (Eleuthera Island, Bahamas). Sedimentology 51, 745765.

Evans, G., Schmidt, V., Bush, P., Nealson, H., 1969. Stratigraphy and geologic history of the sabkha, Abu Dhabi, Persian Gulf. Sedimentology 12, 145-159.

Eugster, H.P., Hardie, L.A., 1978. Saline lakes. In: Lerman, A. (Ed.), Lakes. Chemistry, Geology, Physics. Springer-Verlag, New York, pp. 237-294.

Fort, R., Calvo, J.P., García del Cura, M.A., Ordóñez, S., 1982. Selenite fabrics in Lower Miocene Gypsum of the Madrid Basin (Spain). IAS Third European Meeting. Copenhagen, pp. 11-13. Fortin,

D., Ferris, F.G., Beveridge, T.J., 1997. Surface mediated

mineral development by bacteria. In: Banfield, J.F., Nealson, K.H.(Eds.), Geomicrobiology: Interactions between Microbes and Minerals. Reviews in Mineralogy. Mineralogical Society of America, Washington D.C., pp. 161-180.

García del Cura, M.A., Calvo, J.P., Ordoñez, S., Jones, B.F., Cañaveras, J.C., 2001. Petrographic and geochemical evidence for the for-mation of primary, bacterially induced lacustrine dolomite: La Roda "white earth" (Pliocene, central Spain). Sedimentology 48, 897-915.

García-Veigas, J., 1993. Geoquímica de inclusiones fluidas en formaciones salinas: microanálisis Cryo-SEM-EDS. Ph. D. Thesis, Universidad de Barcelona, Spain.

Gerdes, G., Krumbein, W.E., Noffke, N., 2000. Evaporite microbial sediments. In: Riding, R.E., Awramik, S.M. (Eds.), Microbial Sediments. Springer-Verlag, Berlin, pp. 196-208.

Goldsmith, J.R., Graf, D.L., 1958. Relations between lattice constraints and composition of the $\mathrm{Ca}-\mathrm{Mg}$ carbonates. American Mineralogist 43, 84-1001.

Goldsmith, J.R., Graf, D.L., Heard, H.C., 1961. Lattice constants of the calcium-magnesium carbonates. American Mineralogist 46, 453457.
Goldstein, R.H., Reynolds, T.J., 1994. Systematics of fluid inclusions in diagenetic minerals. SEPM Short Course 31.

Golubic, S., Friedmann, I., Schneider, J., 1981. The lithobiontic ecological niche, with special reference to microorganisms. Journal of Sedimentary Petrology 51, 475-478.

Hardy, R., Tucker, M., 1988. X-ray powder diffraction of sediments. In: Tucker, M. (Ed.), Techniques in Sedimentology. Blackwell Scientific Publications, Oxford, pp. 191-228.

Kelts, K., McKenzie, J.A., 1982. Diagenetic dolomite formation in Quaternary anoxic diatomaceous muds of Deep Sea Drilling Project Leg 64, Gulf of California. In: Curray, J.R., Moore, D.G.(Eds.), Init. Repts. DSDP, 64 (Pt. 2). U.S. Govt. Printing Office, Washington, pp. 553-569.

Kinsman, D.J.J., 1964. The recent carbonate sediments near Halat al Bahrani, Trucial Coast, Persian Gulf. In: Van Straaten, L.M.J.U.(Ed.), Deltaic and Shallow Marine Deposits. Developments in Sedimentology, vol. 1. Elsevier, Amsterdam, pp. 184-192.

Last, W.M., 1990. Lacustrine dolomite - an overview of modern, Holocene, and Pleistocene occurrences. Earth-Science Reviews 27, 221-263.

Léveillé, R.J., Fyfe, W.S., Longstaffe, F.J., 2000. Geomicrobiology of carbonate-silicate microbialites from Hawaian basaltic sea caves. Chemical Geology 169, 339-355.

Léveillé, R.J., Fyfe, W.S., Longstaffe, F.J., 2002. Unusual secondary $\mathrm{Ca}-\mathrm{Mg}-$ Carbonate-Kerolite deposits in basaltic caves, Kauai, Hawaii. Journal of Geology 108, 613-621.

Machel, H.G., Mountjoy, E.W., 1986. Chemistry and environments of dolomitization - a reappraisal. Earth-Science Reviews 23, 175222 .

McKenzie, J.A., Hsu, K.J., Schneider, J.F., 1980. Movement of subsurface waters under the sabkha, Abu Dhabi, UAE, and its relation to evaporative dolomite genesis. In: Zenger, D.H. (Ed.), Concepts and Models of Dolomitization. Society of Economic Paleontologists and Mineralogists, vol. 28, pp. 147-185.

Meister, P., McKenzie, J.A., Warthmann, R., Vasconcelos, C., 2006. Mineralogy and Petrography of Diagenetic Dolomite, Peru Margin, ODP Leg 201. In: Jorgensen, B.B., D'Hondt, S.L., Miller, D.J. (Eds.), Proc. ODP, Sci. Results, vol. 201, pp. 1-34.

Moreira, N.L., Walter, L.M., Vasconcelos, C., McKenzie, J.A., McCall, P.J., 2004. Role of sulfide oxidation in dolomitization: sediment and pore-water geochemistry of a modern hypersaline lagoon system. Geology 32, 701-704.

Ogniben, L., 1954. La "regola di Mottura" di orientazione del gesso. Periodico di Mineralogia 23, 53-65.

Oren, A., Kühl, M., Karsen, U., 1995. An endoevaporitic microbial mat within a gypsum crust: zonation of phototrops, photopig-ments, and light penetration. Marine Ecology Progress Series 128, 151-159.

Ortí-Cabo, F., Pueyo-Mur, J.J., Geisler-Cussey, D., Dulau, N., 1984. Evaporitic sedimentation in the coastal salinas of Santa Pola (Alicante, Spain). Revista Investigaciones Geológicas 38-39, 169220 .

Peryt, T.M., Peryt, D., Jasionowski, J., Poberezhskyy, A.V., Durakiewicz, T., 2004. Post-evaporitic restricted deposition in the Middle Miocene Chokrakian-Karaganian of East Crimea (Ukraine). Sedi-mentary Geology 170, 21-36.

Rao, V.P., Kessarkar, P.M., Krumbein, W.E., Krajewski, K.P., Scheider, R.J., 2003. Microbial dolomite crusts from the carbonate platform off Western India. Sedimentology 50, 819-830. Roberts, J.A.,

Bennett, P.C., Gónzalez, L.A., Macpherson, G.L., Miliken, K.L., 2004. Microbial precipitation of dolomite in methanogenic groundwater. Geology 32, 277-280. 
Rodríguez-Aranda, J.P., Rouchy, J.M., Calvo, J.P., Ordoñez, S., García del Cura, M.A., 1995a. Unusual twining features in large primary gypsum crystals formed in salt lake conditions, Middle Miocene, Madrid Basin, Spain. Palaeoenvironmental implications. Sedi-mentary Geology 95, 123-132.

Rodríguez-Aranda, J.P., Rouchy, J.M., Calvo, J.P., Ordoñez, S., García del Cura, M.A., 1995b. Unusual twining features in large primary gypsum crystals formed in salt lake conditions, Middle Miocene, Madrid Basin, Spain. Palaeoenvironmental implications-reply. Sedimentary Geology 100, 183-186.

Rodríguez-Aranda, J.P, Sanz-Montero, M.E., Calvo, J.P., 2004. Comunidades microbianas endoevaporíticas relacionadas con la precipitación de dolomita en ambiente lacustre salino: Mioceno de la Cuenca de Madrid. Geotemas 6 (2), 115-118.

Rodríguez-Navarro, C., Sebastian, E., Rodríguez-Gallego, M., 1997. An urban model for dolomite precipitation: authigenic dolomite on weathered building stones. Sedimentary Geology 109 (1-2), 1-11.

Roedder, E., 1984a. Fluid Inclusions. Reviews in Mineralogy, vol. 12. Mineralogical Society of America, Washington DC.

Roedder, E., 1984b. The fluids in salt. American Mineralogist 69, 413-439.

Rosen, M.R., Miser, D.E., Starcher, M.A., Warren, J.K., 1989. Formation of dolomite in the Coorong region, south Australia. Geochimica et Cosmochimica Acta 53, 661-669.

Sanz-Montero, M.E., Rodríguez-Aranda, J.P., Calvo, J.P., 2003. Dolomias primarias de ambiente lacustre salino: Mioceno de la Cuenca de Madrid. Geotemas 5, 209-212.

Sanz-Montero, M.E., Rodríguez-Aranda, J.P., Calvo, J.P., 2006. Mediation of endoevaporitic microbial communities in early replacement of gypsum by dolomite: a case study from Miocene lake deposits of the Madrid Basin, Spain. Journal of Sedimentary Research $76,1257-1266$.

Sanz-Montero, M.E., Rodríguez-Aranda, J.P., García del Cura, M.A. (in review) Dolomite-silica stromatolites in Miocene lacustrine deposits from the Duero Basin, Spain: The role of organotemplates in the precipitation of dolomite. Sedimentology.

Schultze-Lam, S., Beveridge, T.J., 1994. Nucleation of celestite and strontianite on a cyanobacterial S-layer. Applied and Environmental Microbiology 60, 447-453.

Schultze-Lam, S., Fortin, D., Davis, B.S., Beveridge, T.J., 1996. Mineralization of bacterial surfaces. Chemical Geology 132, 171181.

Souza-Egipsy, V., Wierzchos, J., Ascaso, C., 2002. Ultrastructural and biogeochemical features of microbiotic soil crusts and their implications in a semiarid habitat. Geomicrobiology Journal 19, 567-580. Souza-

Egipsy, V., Wierzchos, J., Ascaso, C., Nealson, K.H., 2005.

Mg-silica precipitation in fossilization mechanisms of sand tufa endolithic microbial community, Mono Lake (California). Chem-ical Geology 217, 77-87.
Thompson, J.B., Ferris, F.G., 1990. Cyanobacterial precipitation of gypsum, calcite, and magnesite from natural alkaline lake water. Geology 18, 995-998

van Lith, Y., Vasconcelos, C., Warthmann, R., Martins, J., McKenzie, J., 2002. Bacterial sulfate reduction and salinity: two controls on dolomite precipitation in Lagoa Vermelha and Brejo do Espinho (Brazil). Hydrobiologia 485 (1-3), 35-49.

van Lith, Y., Warthmann, R., Vasconcelos, C., McKenzie, J.A., 2003. Microbial fossilization in carbonate sediments: a result of the bacterial surface involvement in dolomite precipitation. Sedimen-tology $50,237-245$.

Vasconcelos, C., McKenzie, J.A., 1997. Microbial mediation of modern dolomite precipitation and diagenesis under anoxic conditions (Lagoa Vermelha, Rio de Janeiro, Brazil). Journal of Sedimentary Research 67, 378-390.

Vasconcelos, C., McKenzie, J.A., Bernasconi, S.M., Grajic, D., Tien, A.J., 1995. Microbial mediation as a possible mechanism for natural dolomite formation at low temperature. Nature 377, 220-222.

Verrecchia, E.P., Freytet, P., Verecchia, K.E., Dumont, J.L., 1995. Spherulites in calcrete laminar crusts: biogenic $\mathrm{CaCO}_{3}$, precipi-tation as a major contributor to crust formation. Journal of Sedi-mentary Research A65, 690-700

Von der Borch, C.C., 1976. Stratigraphy and formation of Holocene dolomitic carbonate deposits of the Coorong area, South Australia. Journal of Sedimentary Petrology 46 (4), 952-966.

Warren, J., 1999. Evaporites: Their Evolution and Economics. Blackwell Science. 438 pp.

Warthmann, R., Vasconcelos, C., Sass, H., McKenzie, J.A., 2005. Desulfovibrio brasiliensis sp. nov., a moderate halophilic sulfatereducing bacterium from Lagoa Vermelha (Brasil) mediating dolomite formation. Extremophiles 9, 255-261.

Wheeler, A.P., Sikes, C.S., 1984. Regulation of carbonate calcification by organic matrix. American Zoologist 24 (4), 933-944. Wierzchos, J.,

Ascaso, C., 1994. Application of back-scattered electron imaging to the study of the lichen-rock interface. Journal of Microscopy 175, 54-59.

Wright, D.T., 1999. The role of sulphate-reducing bacteria and cyanobacteria in dolomite formation in distal ephemeral lakes of the Coorong region, south Australia. Sedimentary Geology 126, 147-157.

Wright, D.T., Wacey, D., 2005. Precipitation of dolomite using sulphate-reducing bacteria from the Coorong Region, south Australia: significance and implications. Sedimentology 52, 9871008 . 